(c) American Dairy Science Association, 2005.

\title{
Statistical Evaluation of Factors and Interactions Affecting Dairy Herd Improvement Milk Urea Nitrogen in Commercial Midwest Dairy Herds
}

\author{
M. A. Wattiaux ${ }^{1}$, E. V. Nordheim, ${ }^{2}$ and P. Crump ${ }^{3}$ \\ ${ }^{1}$ Department of Dairy Science, ${ }^{2}$ Department of Statistics and Department of Forest Ecology and Management, \\ and ${ }^{3}$ Department of Computing and Biometry, University of Wisconsin, Madison 53706
}

\begin{abstract}
In this study, 400,729 Dairy Herd Improvement (DHI) records collected on 77,178 cows in 692 Midwest herds over 29 mo (January 1999 to May 2001) were used to analyze milk urea nitrogen (MUN) as collected the day of the test in 6 breeds. Records of Holsteins, Jerseys, and Brown Swiss were subjected to stepwise backward elimination analysis with a model including parity (primiparous vs. multiparous cows), sample type (morning vs. evening), milking frequency $(2 \times$ vs. $3 \times$ [Holstein only]), season (winter, spring, summer, and fall), yield of fat-corrected milk (FCM) classified into 1 of $3 \mathrm{FCM}$ categories (FCMc) and all possible higherorder interactions. Results indicated that FCMc contributed to test-day MUN variation in multiparous, but not primiparous, Holsteins. Sample type and season were significant in both parity groups; milking frequency was not significant, but milking frequency $\times$ season and milking frequency $\times$ FCMc were significant in both parity groups. The nature of these interactions differed for each parity group. For Jersey and Brown Swiss data analyzed by sample type separately, parity was not significant but tended to interact with FCMc, whereas season, FCMc, and season $\times$ FCMc were generally significant. Mean test-day MUN was 12.7, 14.6, and $14.4 \mathrm{mg} / \mathrm{dL}$, with 24,45 , and $42 \%$ of records above $14.5 \mathrm{mg} / \mathrm{dL}$ in Holsteins, Jerseys, and Brown Swiss in single-breed herds, respectively. In Holsteins, MUN peaked at 7 to $10 \mathrm{~d}$ in milk (DIM), declined until 28 to $35 \mathrm{DIM}$, and rose again thereafter. In primiparous Holsteins, MUN did not change with FCM $\leq 42 \mathrm{~kg} / \mathrm{d}$, but for higher FCM yield, MUN declined linearly by $0.05 \mathrm{mg} / \mathrm{dL}$ per kilogram of FCM. In multiparous Holsteins, MUN increased by 0.06 and $0.03 \mathrm{mg} / \mathrm{dL}$ per kilogram of FCM as FCM yield increased from 5 to 29 and from 30 to $59 \mathrm{~kg} / \mathrm{d}$, respectively, but decreased by 0.06 $\mathrm{mg} / \mathrm{dL}$ as FCM yield increased from 60 to $85 \mathrm{~kg} / \mathrm{d}$. The use of adjustment coefficients may facilitate interpreta-
\end{abstract}

Received December 19, 2004.

Accepted April 22, 2005.

Corresponding author: M. A. Wattiaux; e-mail: wattiaux@ wisc.edu. tion of test-day MUN on commercial herds. Research should focus on the biological significance of the pattern of change in MUN the first few weeks postpartum and the drop in MUN in unusually high-producing cows. (Key words: environment, Dairy Herd Improvement, nitrogen, hierarchical backward elimination) Abbreviation key: FCMc = fat-corrected milk
category.

\section{INTRODUCTION}

Milk urea nitrogen can be used as an indicator of the adequacy of protein and the balance between energy and protein in lactating dairy cow diets (Broderick and Clayton, 1997; Wattiaux and Karg, 2004a) and as a predictor of urinary nitrogen excretion (Kauffman and St Pierre, 2001; Kohn et al., 2002; Wattiaux and Karg, 2004b). Thus, MUN has the potential to be a multifunctional indicator of $\mathrm{N}$ efficiency of dairy herds, helping producers to fine-tune rations while minimizing the excretion of environmentally vulnerable N (Jonker et al., 2002). Although "target" ranges of MUN have been proposed (Hof et al., 1997; Kohn et al., 2002), its use as a management tool on farms remains uncertain because of permanent or temporary effects specific to herds (e.g., rolling herd average for milk production; RajalaSchultz and Saville, 2003), cows within a herd (e.g., breed, parity, stage of lactation; Godden et al., 2001), DHI test-day level of milk production (Johnson and Young, 2003), method of sampling (morning vs. evening; Godden et al., 2001), method of analysis (Peterson et al., 2004; Kohn et al., 2004), and time-dependent factors such as month (Arunvipas et al., 2003) or season (Godden et al., 2001). In addition, the usefulness of MUN determined under field conditions depends on the availability of representative milk samples for a group of cows (Godden et al., 2002) or the averages of sufficient records of individual cows fed a particular diet. In the absence of specific nutritional information, the partitioning of variations in MUN between nutritional and nonnutritional factors is difficult because some of the aforementioned effects are at least partially confounded with feeding practices. Nevertheless, the removal of 
systematic biases and thus the adjustment of test-day MUN to a common base may improve its dependability in assessing the adequacy of the diet. Thus, the main objective was to evaluate the relative impact of selected variables and their interactions on MUN as collected on the day of the DHI test. The second objective was to derive adjustment coefficients for Holstein, Jersey, and Brown Swiss test-day MUN.

\section{MATERIALS AND METHODS}

The database used in this retrospective study was obtained from Ag Source (Verona, WI) and included all records collected from 5 states (Illinois, Michigan, Wisconsin, Minnesota, and Iowa) for a period of $29 \mathrm{mo}$ starting January 1999 and ending May 2001. The DHI technicians collected all samples and individual cow data during their regular monthly farm visits. The original data were in 2 separate files, one with individual cow test-day records and another with herd-level information. The test-day data file included a test date, a herd code identifier (state, county, and herd), a cow identifier, breed, parity, DIM, milking frequency (2 or 3 milkings/d), milk yield, fat percent, protein percent, SCC, MUN, and a code identifying cows that were sick, in heat, or that had calved within $6 \mathrm{~d}$ of the test-day. The herd-level data file included a test date, a herd code (state, county, and herd), a sample type indicator (morning, evening, or composite), the rolling herd average for cow number and for milk production. Herds removed from the study were those with unknown sample type (i.e., uncertain sampling time), a small number of cows $(<5)$, or a low rolling herd average for milk $(<1000 \mathrm{~kg} / \mathrm{cow}$, Table 1). The herd-level file was then merged with the test-day file based on herd code and test date. The merged data set included unique test-day records of cows unequivocally identified as belonging to unique herds.

Laboratory measurements were performed by $\mathrm{Ag}$ Source (Menomonie, WI), a national DHIA-accredited laboratory, using the combiFoss 5000 (Foss Electric, Hillerød, Denmark), which included the MilkoScan 4000 for determination of milk components and MUN by infrared analysis. Fat-corrected milk was calculated with the Gaines' formula $(4 \% \mathrm{FCM}, \mathrm{kg} / \mathrm{d}=0.4 \times$ milk, $\mathrm{kg} / \mathrm{d}+15 \times$ fat, $\mathrm{kg} / \mathrm{d}$; NRC 2001). Although DHI does not report MUN for cows with DIM $<6$ on test-day, these records were available and included in the study. In contrast, records were removed for DIM $>730$ (i.e., a lactation $>2 \mathrm{yr}$ ) and breeds other than Ayrshire, Brown Swiss, Guernsey, Holstein, Jersey, or Milking Shorthorn. A limited number of records with extremes in milk production and composition also were removed, as shown in Table 1. Ultimately, the data set used for analysis included 400,729 records from 77,178 individual cows distributed in 692 herds.

\section{Statistical Analyses}

Descriptive statistics. Using PROC MEANS of SAS (SAS Inst., Inc., Cary, NC), test-day records were averaged for each individual cow and each individual herd to obtain aggregate MUN means at the cow level and at the herd level. Using PROC UNIVARIATE, the number of records in each mean was recorded to describe the distribution of test-day records per cow and per herd (i.e., frequency of testing) and the distribution of cows per herd (i.e., herd size). In addition, descriptive statistics (median, mean, SD, minimum, and maximum) were computed for parity, DIM, MUN, FCM, percentages, and yields of true protein and fat in the milk. Results are given in Table 2.

Breed and temporal variations. Preliminary observations indicated large breed and temporal variations in average test-day MUN. There also appeared to be an effect depending on whether a cow belonged to a herd comprising a single breed or more than 1 breed. The majority of Ayrshire, Guernsey, and Milking Shorthorn were in multiple-breed herds. However, there were 533, 17, and 13 single-breed herds for Holstein, Jersey, and Brown Swiss. PROC MEANS was used to calculate monthly test-day MUN of these 3 breeds and the within-breed deviations due to number of breeds in the herd, parity, season, milking frequency, and sample type. Results were plotted and presented in Figures 1 and 2 , respectively.

ANOVA structure. The share of total test-day MUN variance attributable to herd, cow within herd, and testday within cow and within herd (unexplained residual) was estimated using PROC NESTED for Holsteins, Jerseys, and Brown Swiss in single-breed herds. In addition, distribution of test-day MUN records was described using PROC FREQ and categorized in 1 of 5 groups. Results of these 2 procedures are given in Table 3.

Variation associated with DIM, FCM yield, and parity in Holsteins. The data for primiparous and multiparous Holsteins in single-breed herds were summarized with PROC MEANS by month of lactation, by DIM for the first $73 \mathrm{~d}$ postpartum, and by yield of FCM grouped in incremental categories of $5 \mathrm{~kg} / \mathrm{d}$. Results are in given in Figures 3, 4, and 5.

ANOVA-Holstein data. A 3-mo subset of the data was used to test the feasibility of a mixed-model analysis with repeated measures including herd and cow within herd as random effects along with selected fixed variables. Such analysis was precluded because it exceeded the available computing resources. However, 
PROC GLM was used with a model including fixed effects only and a data set of 96 observations obtained as the means of 5 selected factors arranged in a $2 \times 2$ $\times 2 \times 3 \times 4$ factorial. Factors were parity ( $1 \mathrm{vs} .>1)$, type of sample (morning vs. evening), frequency of milking ( $2 \times$ vs. $3 \times$ ), test-day FCM classified into 1 of 3 categories $(\mathrm{FCMc} ;$ low $=$ bottom third, medium $=$ middle third and high $=$ top third), and season $($ winter $=$ December to February, spring $=$ March to May, summer $=$ June to August, and fall $=$ September to November). The use of a limited number of categories for each factor was to facilitate interpretation of interactions. The initial model included the 5 main effects (parity, sample type, milking frequency, season, and FCMc), their 10 twoway interactions, 10 three-way interactions, and 5 fourway interactions. Many of the higher-order interactions were highly significant $(P<0.001)$, leading to the need to simplify the model. Because parity and sample type contributed most often to higher-order interactions, each level of these 2 factors was analyzed separately. Based on model $\mathrm{r}^{2}$ and mean square errors, it was concluded that data from primiparous and multiparous Holsteins should be analyzed separately. The following model was used for each parity group:

$$
\begin{gathered}
\mathrm{MUN}_{\mathrm{ijkl}}=\mu+\mathrm{T}_{\mathrm{i}}+\mathrm{M}_{\mathrm{j}}+\mathrm{S}_{\mathrm{k}}+\mathrm{F}_{\mathrm{l}}+\mathrm{TM}_{\mathrm{ij}}+\mathrm{TS}_{\mathrm{ik}} \\
+\mathrm{TF}_{\mathrm{il}}+\mathrm{MS}_{\mathrm{jk}}+\mathrm{MF}_{\mathrm{jl}}+\mathrm{SF}_{\mathrm{kl}}+\mathrm{TMS}_{\mathrm{ijk}} \\
+\mathrm{TMF}_{\mathrm{ijl}}+\mathrm{TSF}_{\mathrm{ikl}}+\mathrm{MSF}_{\mathrm{jkl}}+\mathrm{E}_{\mathrm{ijkl}}
\end{gathered}
$$

where $\mathrm{MUN}_{\mathrm{ijkl}}$ is the dependent variable measured for the $\mathrm{i}$ th sample type ( $\mathrm{T}$, with $\mathrm{i}=1$ to 2 ), the $\mathrm{j}$ th milking frequency ( $\mathrm{M}$, with $\mathrm{j}=1$ to 2 ), the kth season (S, with $\mathrm{k}=1$ to 4 ), and the $\mathrm{l}$ th $\mathrm{FCMc}$ (F, with $\mathrm{l}=1$ to 3 ), and where $\mathrm{TM}_{\mathrm{ij}}, \mathrm{TS}_{\mathrm{ik}}, \mathrm{TF}_{\mathrm{i}}, \mathrm{MS}_{\mathrm{jk}}, \mathrm{MF}_{\mathrm{jl}}, \mathrm{SF}_{\mathrm{kl}}$ represent the 6 two-way interactions, $\mathrm{TMS}_{\mathrm{ijk}}, \mathrm{TMF}_{\mathrm{ijl}}, \mathrm{TSF}_{\mathrm{ikl}}, \mathrm{MSF}_{\mathrm{jkl}}$ represent the 4 three-way interactions, and $\mathrm{E}_{\mathrm{ijk}}$ is the residual error.

Stepwise backward elimination was used to remove nonsignificant terms (main effects and interactions) from each model. According to the hierarchical principle, a lower-order term could not be removed if it was included in a higher-order term declared significant. The threshold value to keep a term in the model was $P \leq 0.01$. Results are given in Table 4 .

ANOVA-Jersey and Brown Swiss data. In the case of Jersey and Brown Swiss, milking frequency was not included in the initial model because of a limited number of $3 \times$ milking records ( $n=47$ and 542 for Jersey and Brown Swiss, respectively). Thus, the initial model included 4 fixed effects, 6 two-way interactions, and 4 three-way interactions. Because of the significance of 3 -way interactions involving parity and sample type, the procedure described above for the Holstein data was repeated to select the most appropriate way to subdivide the data for separate analyses. In this case, it was concluded that morning and evening samples should be analyzed separately. The following model was used for each sample type:

$$
\mathrm{MUN}_{\mathrm{ijk}}=\mu+\mathrm{P}_{\mathrm{i}}+\mathrm{S}_{\mathrm{j}}+\mathrm{F}_{\mathrm{k}}+\mathrm{PS}_{\mathrm{ij}}+\mathrm{PF}_{\mathrm{ik}}+\mathrm{SF}_{\mathrm{jk}}+\mathrm{E}_{\mathrm{ijk}}
$$

where $\mathrm{MUN}_{\mathrm{ijk}}$ is the dependent variable measured for the $i$ th parity (P, with $\mathrm{i}=1$ to 2 ), the $j$ th season ( $\mathrm{S}$, with $\mathrm{j}=1$ to 4 ) and the $k$ th FCMc (F, with $\mathrm{k}=1$ to 3 ), and where $\mathrm{PS}_{\mathrm{ij}}, \mathrm{PF}_{\mathrm{ik}}, \mathrm{SF}_{\mathrm{jk}}$ represent the 3 two-way interactions, and $\mathrm{E}_{\mathrm{ijk}}$ is the residual error.

Stepwise elimination process was used as described above, except that the threshold value to keep a term in the model was $P \leq 0.10$. Depending on the outcome of the elimination process, main effects remaining in final models were declared significant for $P<0.05$, or a tendency for $0.05 \leq P \leq 0.10$. Results are given in Tables 5 and 6 .

\section{RESULTS}

\section{Descriptive Statistics}

Characterization of test-day, cow, and herd records. In this data set, the rolling herd average for milk was $9620 \pm 71 \mathrm{~kg}$ and ranged from 1541 to 15,708 $\mathrm{kg}$ (Table 2). Average number of cows per herd was 101 \pm 4.5 , but the median was 70 , indicating a distribution skewed to the right. Similarly, the frequency of testing among herds was skewed to the right with a mean tests per herd of $7.3 \pm 0.3$, but a median of 3.0. The most common frequency of testing among herds was once. Only 2 of the 692 herds included in this study tested for MUN every month of the study period (i.e., 29 times). Average parity was 2.2 , but the data set included $33,360,18,831,11,755$, and 6813 cows in parity $1,2,3$, and 4 , respectively, leaving 6419 cows with more than four lactations. One cow in the data set had 22 lactations. The frequency of testing a cow within a herd was skewed to the right with a mean, median and mode of $5.2,3.0$, and 1.0, respectively. However in this data set, 3 cows were tested 27 times. Mean test-day FCM was $31.8 \pm 0.02 \mathrm{~kg} / \mathrm{d}$ and ranged from 3.0 to $99.3 \mathrm{~kg} / \mathrm{d}$. Mean DIM was $183 \pm 0.2$ and the most common DIM for MUN testing was 59. The MUN data were normally distributed with a mean of $12.8,12.7$, and $12.9 \mathrm{mg} / \mathrm{dL}$ for test-day, cow and herd records, respectively. The highest MUN for test-day, cow and herd record were $35.0,33.6$, and $22.6 \mathrm{mg} / \mathrm{dL}$, respectively (Table 2).

Temporal variation (year, season, and month). Yearly means $( \pm$ SD) for test-day MUN were $12.7 \pm 3.5$, $12.9 \pm 3.7$, and $12.8 \pm 3.2 \mathrm{mg} / \mathrm{dL}$ for 1999,2000 , and the first 5 mo of 2001, respectively. Variation in monthly 
Table 1. Data set selection criteria.

\begin{tabular}{lcc}
\hline Criteria (deleted if) & $\begin{array}{c}\text { Records } \\
\text { deleted }\end{array}$ & $\begin{array}{c}\text { Records } \\
\text { remaining }\end{array}$ \\
\hline Herd data file (monthly records) & & $6,632^{1}$ \\
Sampling time other than "morning," "evening," or "composite" & 1,538 & 5,094 \\
Rolling herd average for milk <1000 kg/cow & 13 & 5,081 \\
Rolling herd average for cow count <5 cow/herd & 7 & 5,074 \\
Test-day data file (monthly records) & & $401,544^{3}$ \\
DIM > 730 & 659 & 400,885 \\
$4 \%$ FCM < 3 kg/d & 83 & 400,802 \\
$4 \%$ FCM $>100 \mathrm{~kg} / \mathrm{d}$ & 29 & 400,773 \\
Milk fat < 0.25\% & 12 & 400,761 \\
Milk fat $>9.5 \%$ & 23 & 400,738 \\
Milk true protein < 0.25\% & 2 & 400,736 \\
Milk true protein $>9.5 \%$ & 2 & 400,734 \\
MUN $>36$ mg/dL & 5 & 400,729 \\
MUN < 0.1 mg/dL & 0 & 400,729 \\
\hline
\end{tabular}

\footnotetext{
${ }^{1}$ Initial number of records in the herd data file.

${ }^{2}$ Either milking time or sample count were not reported or not stored.

${ }^{3}$ Individual test-day records from cows in the test-day data file that matched a herd identification and test-date in the herd file. Records of sick cows $(n=4170)$ and cows of a breed other than Brown Swiss, Jersey, Holstein, Ayrshire, Guernsey, or Milking Shorthorn $(\mathrm{n}=2436)$ were excluded.
}

test-day MUN was much greater for Brown Swiss and Jerseys compared with Holsteins (Figure 1). This effect might be due in part to differences in sample size. However, even within the Holstein breed, for which the average number of observations per month was 13,352, test-day MUN ranged from a low $11.7 \pm 0.02$ in March 2000 to a high $15.1 \pm 0.03 \mathrm{mg} / \mathrm{dL}$ in August of the same year. Seasonal effects varied from year to year. For example, winter averages were $12.8 \pm 0.02,13.2 \pm 0.02$, and $12.5 \pm 0.02 \mathrm{mg} / \mathrm{dL}$ for 1999 (December 1998 data unavailable), 2000, and 2001, respectively; and corresponding spring values were $12.8 \pm 0.02,12.1 \pm 0.02$, and $13.0 \pm 0.02 \mathrm{mg} / \mathrm{dL}$. In the summer of 2001 , testday MUN was $1.0 \mathrm{mg} / \mathrm{dL}$ higher than in the summer of $2000(14.0 \pm 0.02$ vs. $13.0 \pm 0.02 \mathrm{mg} / \mathrm{dL})$, but the difference in the fall was only $0.2 \mathrm{mg} / \mathrm{dL}(12.6 \pm 0.02$ and $12.4 \pm 0.01 \mathrm{mg} / \mathrm{dL}$, respectively).

Variation associated with breed, breed per herd, parity, season, milking frequency, and sample type. Average test-day MUN for Ayrshire ( $\mathrm{n}=728$, Guernsey $(\mathrm{n}=1609)$, and Milking Shorthorn $(\mathrm{n}=146)$ was $14.7 \pm 0.15,15.6 \pm 0.10$, and $13.4 \pm 0.27 \mathrm{mg} / \mathrm{dL}$, respectively. Average test-day MUN for Holstein, Jersey, and Brown Swiss and within-breed deviations due to parity, season, milking frequency, sample type, and the number of breeds in the herd are illustrated in Figure 2. Overall, MUN was $12.8 \pm 0.01,14.0 \pm 0.06$, and $14.8 \pm 0.06 \mathrm{mg} / \mathrm{dL}$ for Holsteins, Jerseys, and Brown Swiss, respectively. Although Holstein records were relatively unaffected by the number of breeds in the herd,

Table 2. Descriptive DHI measures for herd, cow, and test-day records.

\begin{tabular}{lccccc}
\hline Item & Median & Mean & SD & Min. & Max. \\
\hline Unique herd records (n =692) & & & & & \\
Rolling herd average milk, kg & 9,784 & 9,620 & 1,875 & 1,541 & 15,708 \\
Rolling herd cow count & 70 & 101 & 117.6 & 6 & 1852 \\
DHI testing frequency, test/herd & 3.0 & 7.3 & 7.8 & 1 & 29 \\
MUN, mg/dL & 12.69 & 12.85 & 2.18 & 5.9 & 22.3 \\
Unique cow records (n = 77,178) & & & & & \\
Parity & 2.0 & 2.2 & 1.5 & 1 & 22 \\
DHI testing frequency, test/cow & 3.0 & 5.2 & 5.9 & 1 & 27 \\
MUN, mg/dL & 12.62 & 12.74 & 2.87 & 0.10 & 33.6 \\
Test-day records (n = 400,729) & & & & & \\
FCM, kg/d & 31.3 & 31.8 & 9.9 & 3.0 & 99.3 \\
True protein yield, kg/d & 0.99 & 1.00 & 0.29 & 0.04 & 3.10 \\
Fat yield, kg/d & 1.20 & 1.23 & 0.41 & 0.03 & 5.05 \\
True protein, \% & 3.00 & 3.06 & 0.37 & 0.28 & 9.30 \\
Fat, \% & 3.70 & 3.79 & 0.78 & 0.30 & 9.50 \\
DIM & 168 & 183 & 123 & 1 & 730 \\
MUN, mg/dL & 12.70 & 12.84 & 3.51 & 0.10 & 35.0 \\
\hline
\end{tabular}




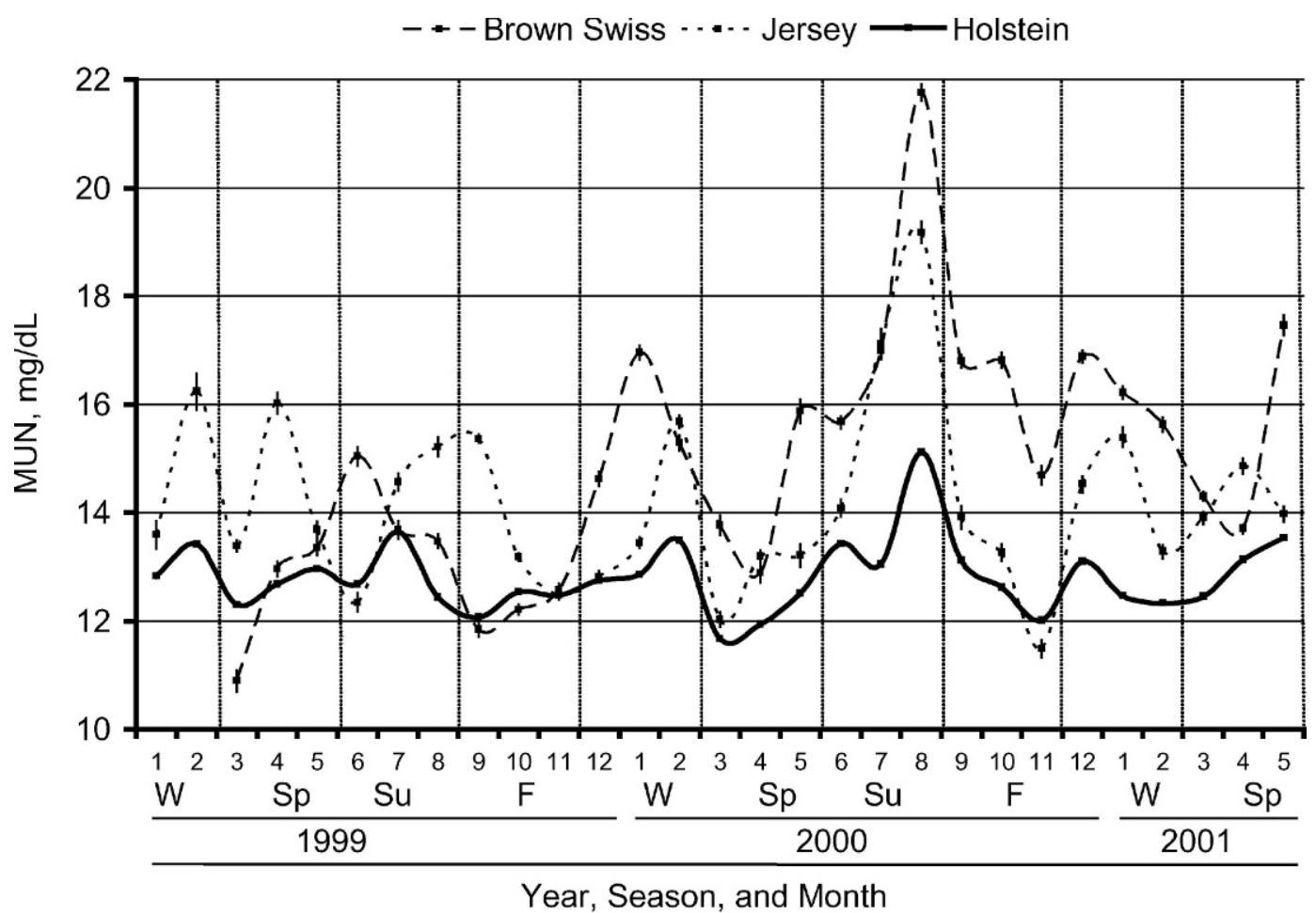

Figure 1. Variation in Holstein $(\mathrm{n}=387,206)$, Jersey $(\mathrm{n}=5544)$, and Brown Swiss $(\mathrm{n}=5496)$ test-day MUN for the 29-mo study period $(\mathrm{W}=$ winter, $\mathrm{Sp}=$ spring, $\mathrm{Su}=$ summer, and $\mathrm{F}=$ fall). Vertical bars (when visible) are $\mathrm{SE}$.

test-day MUN in Jerseys was $0.59 \mathrm{mg} / \mathrm{dL}$ above breed average when belonging to a herd of only Jerseys ( 14.6 $\mathrm{mg} / \mathrm{dL}$ in single-breed herds), but $0.58 \mathrm{mg} / \mathrm{dL}$ below breed average when belonging to a herd in which Jerseys were present with at least one other breed (13.4 $\mathrm{mg} / \mathrm{dL}$ in multiple-breed herds, Figure 2). In the case of Brown Swiss, the difference was in the opposite direction and was $0.81 \mathrm{mg} / \mathrm{dL}$ greater for those in multiplebreed herds compared with single-breed herds (15.2 vs. $14.4 \mathrm{mg} / \mathrm{dL}$, respectively).

The magnitude of the parity effect was relatively minor and dwarfed by the impact of season in all 3 breeds.

Table 3. Characteristics of MUN data including partition of variance among test-day within cow and herd, cow within herd, and herd for records of Holsteins, Jerseys, and Brown Swiss in single-breed herds.

\begin{tabular}{|c|c|c|c|c|c|c|c|c|c|}
\hline \multirow[b]{2}{*}{ Item } & \multicolumn{3}{|c|}{ Holstein } & \multicolumn{3}{|c|}{ Jersey } & \multicolumn{3}{|c|}{ Brown Swiss } \\
\hline & Test-day & Cow & Herd & Test-day & Cow & Herd & Test-day & Cow & Herd \\
\hline Total records, n & 387,206 & 73,801 & 647 & 5,544 & 1,544 & 68 & 5,496 & 1,034 & 68 \\
\hline One-breed herd ${ }^{1}, \mathrm{n}$ & 294,031 & 58,454 & 533 & 2,757 & 958 & 17 & 3,107 & 681 & 12 \\
\hline Mean MUN, mg/dL & 12.72 & 12.64 & 12.75 & 14.61 & 15.15 & 14.25 & 14.43 & 13.82 & 13.66 \\
\hline SE & 0.01 & 0.01 & 0.09 & 0.08 & 0.13 & 0.76 & 0.09 & 0.14 & 1.09 \\
\hline Variance $^{2}$ & 8.2 & 1.8 & 2.0 & 8.5 & 2.6 & 5.2 & 14.4 & 1.6 & 8.8 \\
\hline Variance, $\%$ & 69 & 15 & 17 & 52 & 16 & 32 & 58 & 6 & 35 \\
\hline Distribution & 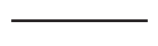 & $\overline{ }$ & $-\mathrm{n}-$ & $\longrightarrow$ & 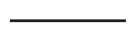 & $-n-$ & $\longrightarrow$ & 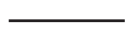 & $-n-$ \\
\hline MUN $\leq 6.4$ & 4.2 & 1.4 & 1 & 2.7 & 2.3 & 0 & 4.5 & 2.5 & 0 \\
\hline $6.5 \leq \mathrm{MUN} \leq 9.4$ & 16.6 & 10.3 & 29 & 8.8 & 5.2 & 1 & 12.7 & 8.5 & 1 \\
\hline $9.5 \leq \mathrm{MUN} \leq 14.4$ & 55.3 & 64.7 & 410 & 43.3 & 33.8 & 8 & 41.4 & 46.7 & 7 \\
\hline $14.5 \leq \mathrm{MUN} \leq 18.4$ & 19.7 & 21.0 & 87 & 32.0 & 40.8 & 7 & 25.3 & 33.8 & 3 \\
\hline MUN $\geq 18.5$ & 4.3 & 2.6 & 6 & 13.4 & 17.8 & 1 & 16.1 & 8.5 & 1 \\
\hline
\end{tabular}

\footnotetext{
${ }^{1}$ Included records for which the number of breed in a herd was equal to 1 for the duration of the study period.

${ }^{2}$ Contribution of each level of the nested hierarchy to total variance, which was 12.0, 16.3, and 24.8 (mg/dL) ${ }^{2}$ for Holstein, Jersey, and Brown Swiss data, respectively. Test-day represents the unexplained residual variation, cow accounts for the cow-to-cow variation within a herd, and herd accounts for the variation among herds.
} 


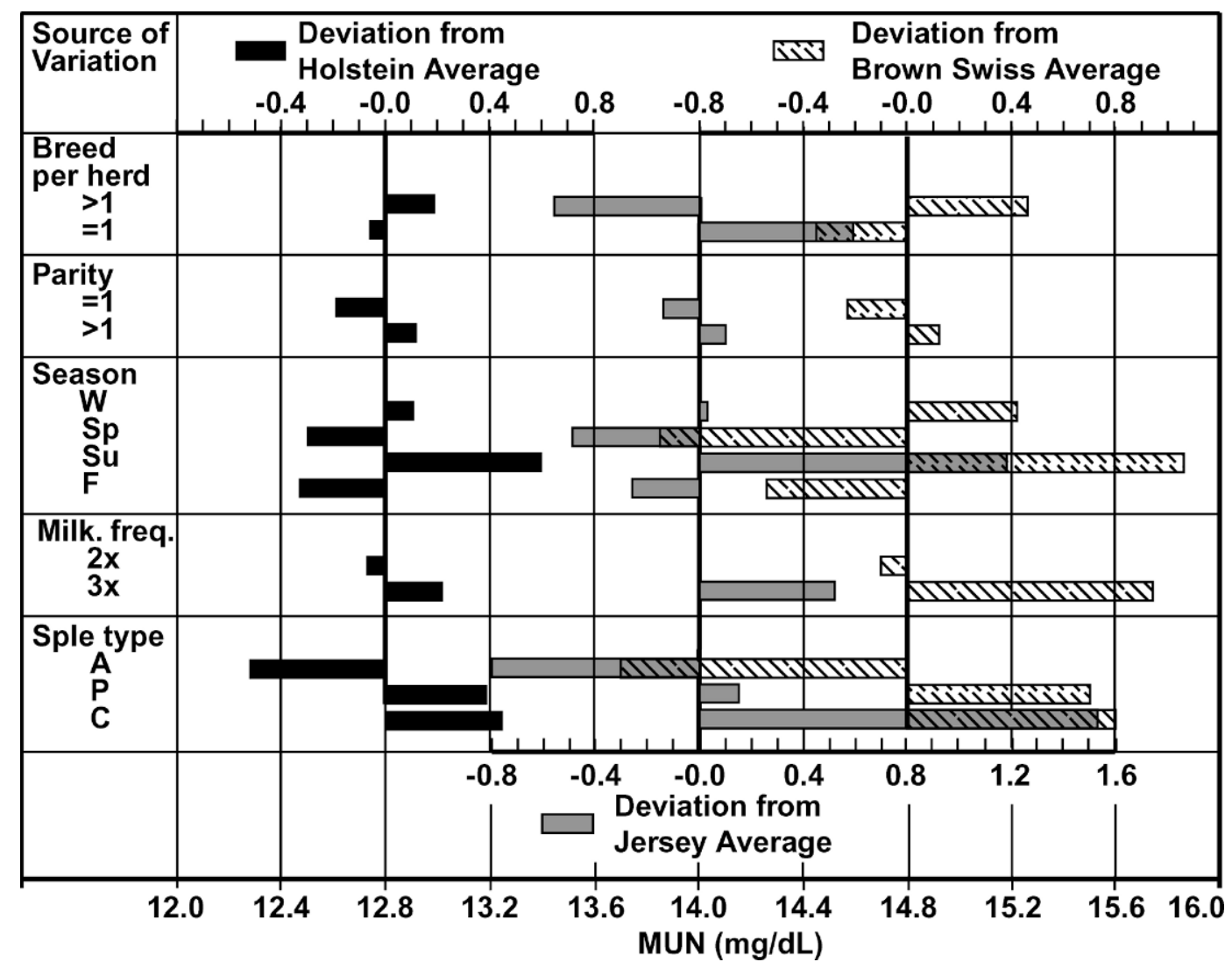

Figure 2. Breed average and deviation from breed average in test-day MUN associated with breed per herd, parity, season (W = winter, $\mathrm{Sp}=$ spring, $\mathrm{Su}=$ summer, and $\mathrm{F}=$ fall), milking frequency $(2 \times$ or $3 \times)$, and sample type (Sple type; $\mathrm{A}=\mathrm{morning}, \mathrm{P}=\mathrm{evening}, \mathrm{C}=\mathrm{composite})$. The average test-day MUN for Holsteins $(\mathrm{n}=387,206)$, Jersey $(\mathrm{n}=5544)$, and Brown Swiss ( $\mathrm{n}=5496)$ was $12.8 \pm 0.01,14.0 \pm 0.06$, and $14.8 \pm 0.06$, respectively.

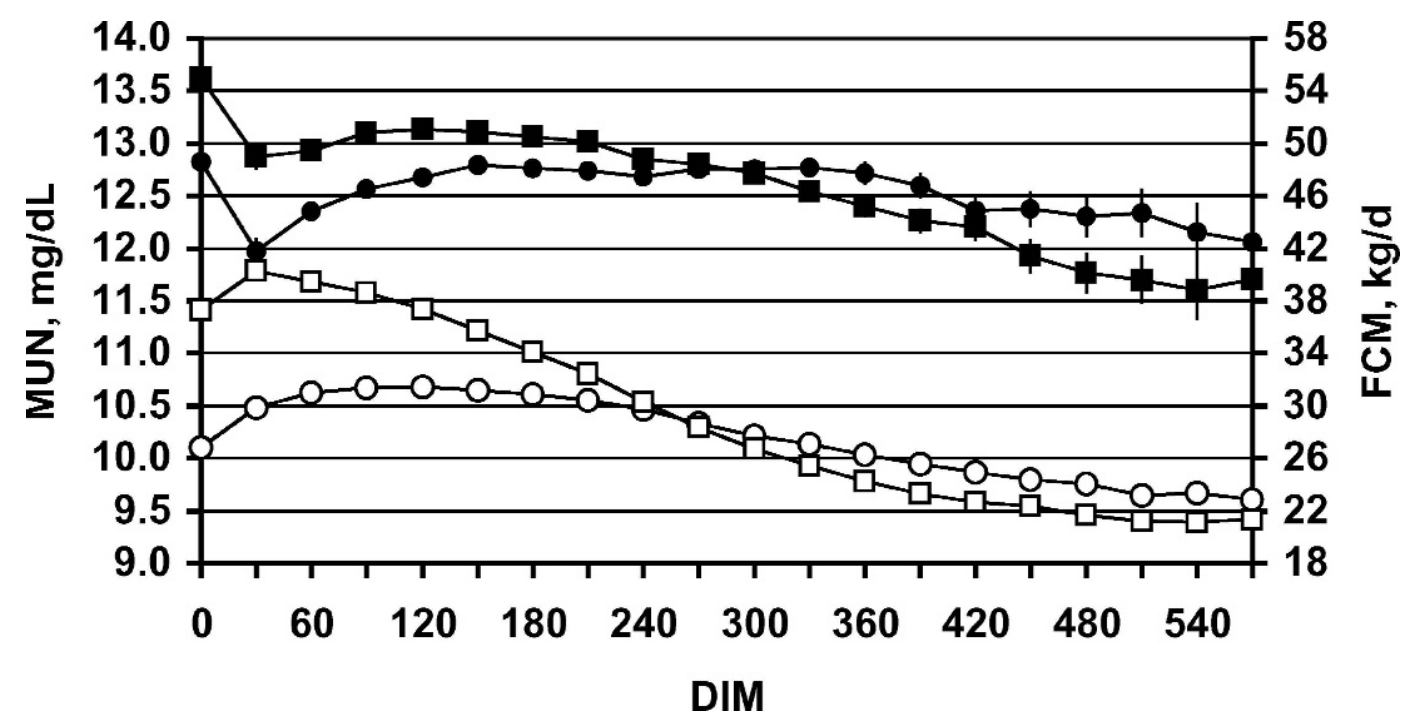

Figure 3. Relationship between DIM, test-day MUN (solid symbols), and 4\% FCM (open symbols) averaged by 30-d intervals in primiparous (circles, $\mathrm{n}=148,285$ ) and multiparous (squares, $\mathrm{n}=236,896)$ Holsteins. Vertical bars (when visible) are SE. 


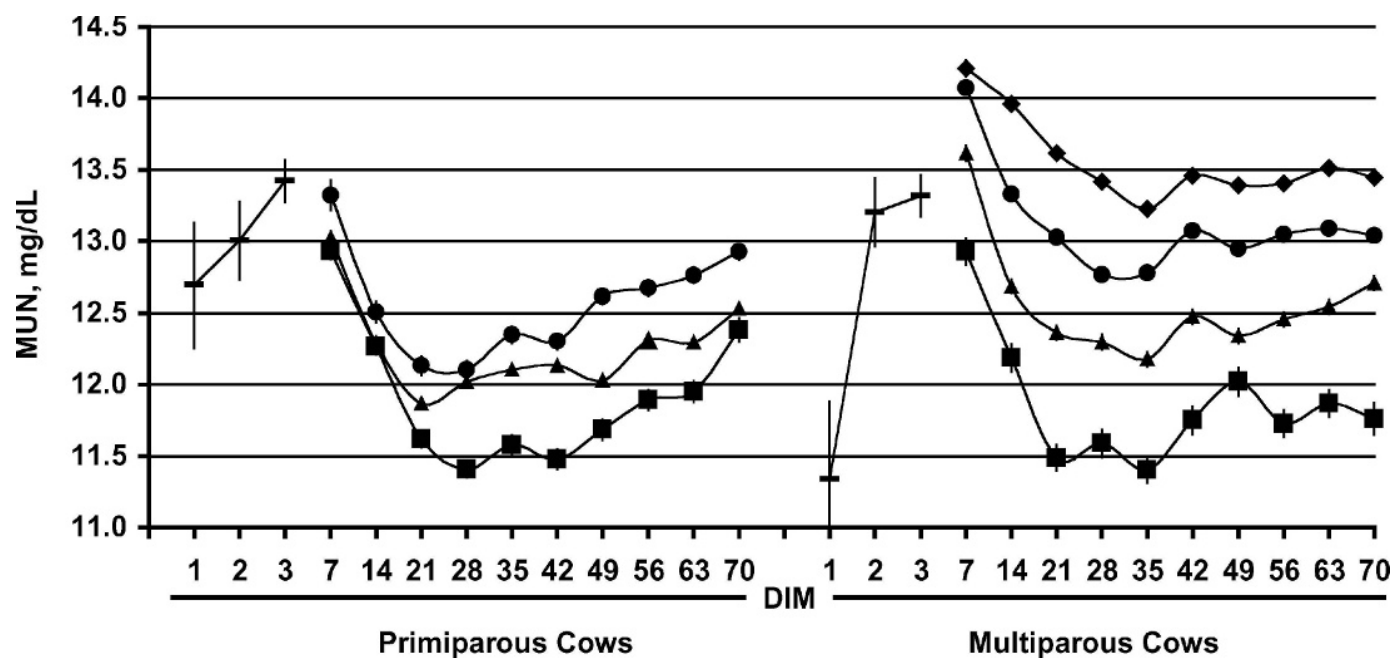

Figure 4. Pattern of change in test-day MUN with DIM, for d 1, 2, and $3(-)$ in primiparous $(\mathrm{n}=339)$ and multiparous Holsteins $(\mathrm{n}=$ $550)$ at all production levels and thereafter in 7-d average from d 4 to 73 in primiparous $(\mathrm{n}=29,980)$ and multiparous Holsteins $(\mathrm{n}=53,566)$ with yield of $4 \% \mathrm{FCM}<25(\boldsymbol{\square}), 25 \leq \mathrm{FCM}<35(\boldsymbol{\Delta}), 35 \leq \mathrm{FCM}<45(\bullet)$, and FCM $\geq 45 \mathrm{~kg} / \mathrm{d}(\bullet$; multiparous cows only). Vertical bars (when visible) are SE.

The pattern of change in MUN with season was consistent for each of the 3 breeds with winter and summer MUN above the mean, and spring and fall MUN below the mean. Cows milked $3 \times$ had greater MUN than those milked $2 \times$ a day. However, the large deviation above the mean for both Jersey and Brown Swiss $3 \times$ records should be interpreted cautiously as they comprised less than 1 $(n=47)$ and $10 \%(n=542)$ of the total records for those two breeds, respectively. In all 3 breeds, sampling type influenced MUN substantially with morning samples consistently below breed average and evening samples above breed average. Interestingly, test-day MUN from composite samples were the highest of the 3 sampling schedules in all 3 breeds. These results indicate that

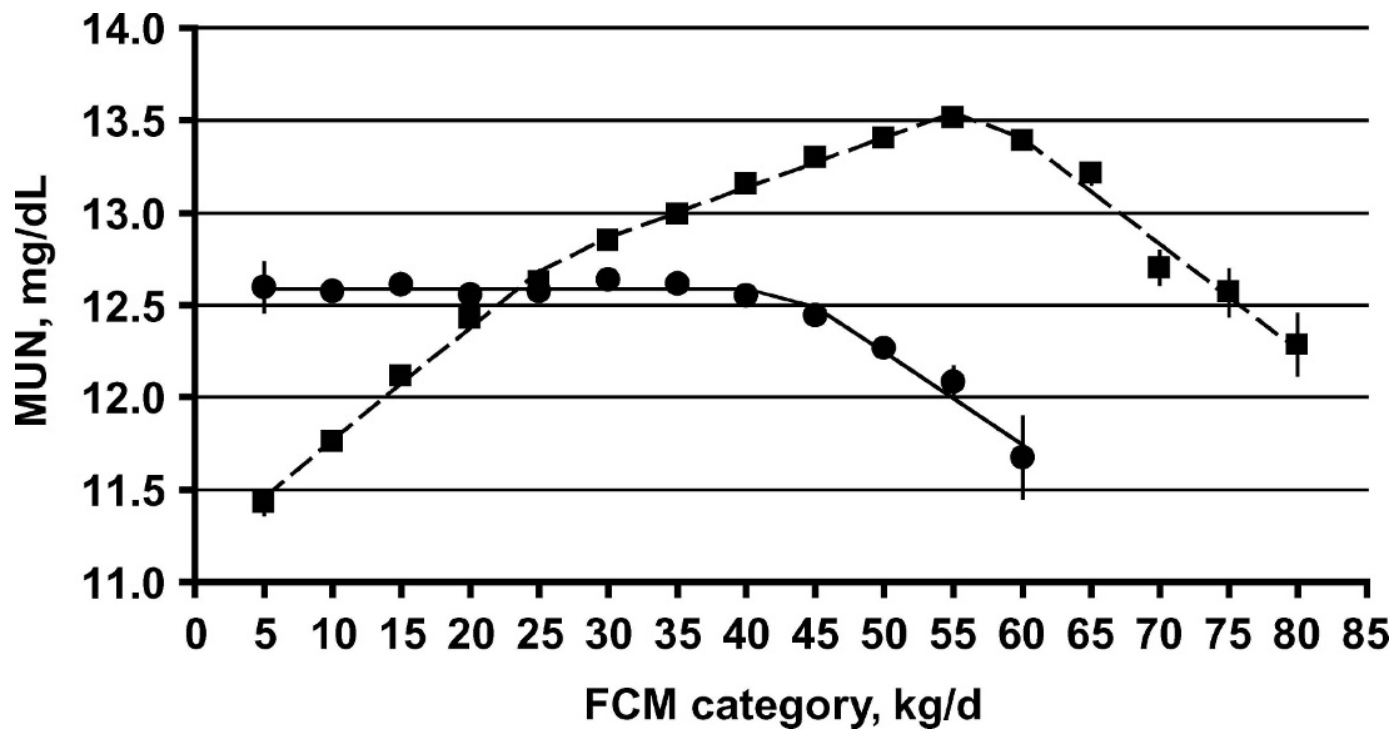

Figure 5. Relationship between test-day MUN and yield of $4 \% \mathrm{FCM}$ categorized in $5 \mathrm{~kg} / \mathrm{d}$ intervals in the range of 3 to $63 \mathrm{~kg} / \mathrm{d}$ in primiparous (-) and in the range of 3 to $83 \mathrm{~kg} / \mathrm{d}$ in multiparous (ם) Holstein. Vertical bars (when visible) are SE. The prediction line for the primiparous cows (solid line) was a composite of two linear segments with a slope of zero $\left(\mathrm{r}^{2}=0.98\right)$ and $-0.050 \pm 0.008 \mathrm{mg} / \mathrm{dL}\left(\mathrm{r}^{2}=\right.$ 0.93 ) for FCM $\leq 42$ and FCM $>42 \mathrm{~kg} / \mathrm{d}$, respectively. The prediction line for the multiparous cows (dashed line) was a composite of three linear segments with a slope of $0.061 \pm 0.003\left(\mathrm{r}^{2}=0.99\right), 0.027 \pm 0.001\left(\mathrm{r}^{2}=0.99\right)$, and $-0.057 \pm 0.006\left(\mathrm{r}^{2}=0.97\right) \mathrm{mg} / \mathrm{dL}$ for FCM $\leq 28,29$ $\leq \mathrm{FCM} \leq 58$, and $\mathrm{FCM}>58 \mathrm{~kg} / \mathrm{d}$, respectively. 
Table 4. Final model ${ }^{1}$ describing the association between average test-day milk urea nitrogen (MUN, dependent variable) and sample type, milking frequency, season, and FCM category in primiparous and multiparous Holsteins.

\begin{tabular}{|c|c|c|c|c|c|c|c|}
\hline \multirow[b]{2}{*}{ Item } & \multirow[b]{2}{*}{$\mathrm{df}$} & \multicolumn{3}{|c|}{ Primiparous $(\mathrm{n}=48)$} & \multicolumn{3}{|c|}{ Multiparous $(\mathrm{n}=48)$} \\
\hline & & MS & $F$-value & $P$-value & MS & $F$-value & $P$-value \\
\hline Sample type ${ }^{2}$ & 1 & 12.645 & 344.2 & $<0.001$ & 9.389 & 213.25 & $<0.001$ \\
\hline $\mathrm{MF}^{3}$ & 1 & 0.004 & 0.1 & 0.75 & 0.095 & 2.16 & 0.15 \\
\hline Season $^{4}$ & 3 & 2.344 & 63.9 & $<0.001$ & 3.365 & 76.42 & $<0.001$ \\
\hline $\mathrm{FCMc}^{5}$ & 2 & 0.060 & 1.6 & 0.21 & 2.402 & 54.55 & $<0.001$ \\
\hline $\mathrm{MF} \times$ season & 3 & 0.229 & 6.2 & 0.002 & 0.194 & 4.41 & 0.010 \\
\hline $\mathrm{MF} \times \mathrm{FCMc}$ & 2 & 0.351 & 9.6 & $<0.001$ & 0.349 & 7.93 & 0.001 \\
\hline Error term & 35 & 0.037 & & $\ldots$ & 0.044 & $\ldots$ & $\ldots$ \\
\hline
\end{tabular}

${ }^{1}$ The complete model included 4 main effects (sample type, milking frequency, season, and FCMc), the 6 two-ways interactions, and the 4 three-way interactions. Adjusted $\mathrm{r}^{2}$ (SAS Inst., Inc., Cary, NC) of initial model was 0.92 and 0.97 for primiparous and multiparous cows, respectively. Adjusted $\mathrm{r}^{2}$ of final model was 0.92 for both primiparous and multiparous cows.

${ }^{2}$ Average test-day MUN was 12.55 and $12.83 \mathrm{mg} / \mathrm{dL}$ for primiparous.

${ }^{2}$ Sample type: morning vs. evening sampling.

${ }^{3}$ Milking frequency: $2 \times$ vs. $3 \times$ per day.

${ }^{4}$ Winter $=$ December to February; Spring $=$ March to May; Summer $=$ June to August Fall $=$ September to November.

${ }^{5}$ FCMc: low $=$ bottom third, medium = middle third, and high $=$ top third $4 \%$ FCM yield. The 33 and 67 percentiles for FCM were 26.4 and $32.6 \mathrm{~kg} / \mathrm{d}$ for primiparous cows, and 28.7 and $38.1 \mathrm{~kg} / \mathrm{d}$ for multiparous cows, respectively.

herds on a composite sampling schedule may have feeding and management practices that lead to higher MUN compared with herds submitting samples from either morning or evening milkings. However, differences due to handling of samples should not be ruled out.

MUN in single-breed herds: Variance structure and distribution. Table 3 summarizes test-day MUN for single-breed herds only. Seventy nine percent of Holstein cows (76\% of the test-day records) were in 533 Holstein-only herds, $62 \%$ of Jersey cows $(50 \%$ of testday records) were in 17 Jersey-only herds, and $66 \%$ of
Brown Swiss cows (57\% of test-day records) were in 12 Brown Swiss-only herds. In this subdataset, test-day MUN was on average $1.9 \mathrm{mg} / \mathrm{dL}$ greater in Jerseys than in Holsteins (14.6 vs. $12.7 \mathrm{mg} / \mathrm{dL}$, respectively), but the difference between Jerseys and Brown Swiss was narrower (14.6 vs. $14.4 \mathrm{mg} / \mathrm{dL}$, respectively).

The ANOVA structure showed that test-day measurements accounted for 69,52 , and $58 \%$ of the total variation in MUN for Holsteins, Jerseys, and Brown Swiss in single-breed herds, respectively (Table 3). For Holsteins, cow-to-cow variation (within a herd) and herd-to-herd

Table 5. Final model ${ }^{1}$ describing the association between average test-day milk urea nitrogen (MUN, dependent variable) and parity season and FCM category in morning and evening samples of Jerseys.

\begin{tabular}{|c|c|c|c|c|c|c|c|c|}
\hline \multirow[b]{2}{*}{ Item } & \multicolumn{4}{|c|}{ Morning samples $(\mathrm{n}=24)$} & \multicolumn{4}{|c|}{ Evening samples $(\mathrm{n}=24)$} \\
\hline & $\mathrm{df}$ & MS & $F$-value & $P$-value & $\mathrm{df}$ & MS & $F$-value & $P$-value \\
\hline Parity $^{2}$ & 1 & 0.419 & 1.25 & 0.29 & 1 & 0.090 & 0.12 & 0.74 \\
\hline Season $^{3}$ & 3 & 5.743 & 17.1 & $<0.001$ & 3 & 3.444 & 4.63 & 0.03 \\
\hline $\mathrm{FCMc}^{4}$ & 2 & 4.658 & 13.9 & 0.002 & 2 & 0.413 & 0.56 & 0.59 \\
\hline FCMc $\times$ season & 2 & 3.480 & 10.4 & 0.005 & 2 & 3.713 & 4.99 & 0.04 \\
\hline FCMc $\times$ parity & 6 & 0.849 & 2.5 & 0.10 & 6 & 2.231 & 3.00 & 0.07 \\
\hline Error term & 9 & 0.336 & $\ldots$ & $\ldots$ & 9 & 0.744 & $\ldots$ & $\ldots$ \\
\hline
\end{tabular}

${ }^{1}$ The complete model included 3 main effects (parity, season, and FCMc) and the 3 two-ways interactions Adjusted $\mathrm{r}^{2}$ (SAS Inst., Inc., Cary, NC) of initial model was 0.89 and 0.70 for morning and evening samples, respectively. Adjusted $\mathrm{r}^{2}$ (SAS Inst., Inc.) of final model was 0.82 and 0.56 for morning and evening samples, respectively.

${ }^{2}$ Parity: primiparous cows vs. multiparous cows.

${ }^{3}$ Seasons: Winter $=$ December to February; Spring $=$ March to May; Summer $=$ June to August; Fall = September to November.

${ }^{4} \mathrm{FCMc}$ : low $=$ bottom third, medium $=$ middle third, and high $=$ top third of $4 \%$ FCM yield. The 33 and 67 percentiles for Jersey test-day FCM records were 22.1 and $28.7 \mathrm{~kg} / \mathrm{d}$ for morning samples and 20.4 and $27.9 \mathrm{~kg} / \mathrm{d}$ for evening samples, respectively. 
Table 6. Final model ${ }^{1}$ describing the association between average test-day milk urea nitrogen (MUN, dependent variable) and parity season and fat-corrected milk category in morning and evening samples of Brown Swiss.

\begin{tabular}{|c|c|c|c|c|c|c|c|c|}
\hline \multirow[b]{2}{*}{ Item } & \multicolumn{4}{|c|}{ Morning samples $(\mathrm{n}=24)$} & \multicolumn{4}{|c|}{ Evening samples $(\mathrm{n}=24)$} \\
\hline & $\mathrm{df}$ & MS & $F$-value & $P$-value & $\mathrm{df}$ & MS & $F$-value & $P$-value \\
\hline Parity $^{2}$ & $\ldots$ & & & & 1 & 0.611 & 1.73 & 0.21 \\
\hline Season $^{3}$ & 3 & 4.451 & 35.1 & $<0.001$ & 3 & 21.074 & 59.5 & $<0.001$ \\
\hline $\mathrm{FCMc}^{4}$ & 2 & 6.179 & 48.7 & $<0.001$ & 2 & 7.906 & 22.3 & $<0.001$ \\
\hline FCMc $\times$ season & 6 & 0.835 & 6.6 & 0.003 & $\ldots$ & & & \\
\hline FCMc $\times$ parity & $\ldots$ & & $\ldots$ & $\ldots$ & 2 & 3.610 & 10.2 & 0.002 \\
\hline Error term & 12 & 0.127 & $\ldots$ & $\ldots$ & 15 & 0.354 & $\ldots$ & $\ldots$ \\
\hline
\end{tabular}

${ }^{1}$ The complete model included 3 main effects (parity, season and FCMc) and the 3 two-ways interactions. Adjusted $\mathrm{r}^{2}$ (SAS Inst., Inc., Cary, NC) of initial and final models were 0.91 for both morning and evening samples.

${ }^{2}$ Parity: primiparous cows vs. multiparous cows.

${ }^{3}$ Winter $=$ December to February; Spring $=$ March to May; Summer $=$ June to August; Fall $=$ September to November.

${ }^{4} \mathrm{FCMc}$ : low $=$ bottom third, medium $=$ middle third, and high $=$ top third of $4 \% \mathrm{FCM}$ yield. The 33 and 67 percentiles for Brown Swiss test-day FCM records were 21.2 and $29.5 \mathrm{~kg} / \mathrm{d}$ for morning samples and 21.8 and $31.3 \mathrm{~kg} / \mathrm{d}$ for evening samples, respectively.

variation contributed approximately equally to total MUN variation, but for the Jerseys and Brown Swiss, herd-to-herd variation was 2 and almost 6 times larger than the cow-to-cow variation, respectively. Table 3 also showed that for Holsteins, $21 \%$ of test-day records, $12 \%$ of cow and $5.6 \%$ (30 out of 533) of herds had MUN $\leq 9.4$ $\mathrm{mg} / \mathrm{dL}$. At the upper end of the distribution, $24 \%$ of testday records, $24 \%$ of cow records and $17 \%$ of herds had MUN $\geq 14.5 \mathrm{mg} / \mathrm{dL}$. The distributions of both test-day and cow records were skewed to the right for the Jerseys and Brown Swiss. The percentage of test-day and cow records above $14.5 \mathrm{mg} / \mathrm{dL}$ was 45 and 59\%, respectively in Jerseys, but 41 and $42 \%$, respectively, in Brown Swiss.

Variation associated with DIM and parity in $\mathrm{Hol}$ steins. Patterns of change in test-day MUN and FCM with DIM in primiparous and multiparous Holsteins in single-breed herds are illustrated in Figure 3. In the first months of lactation, MUN was lower in primiparous than in multiparous cows. As milk production increased between the first and second month of lactation, MUN decreased abruptly in both parity groups, but increased faster in primiparous than in multiparous cows thereafter. In subsequent months, MUN appeared to decline in proportion with milk yield in multiparous cows, but remained relatively constant in primiparous cows. By the 10th month of lactation, both FCM and MUN became greater in primiparous than in multiparous cows.

A more detailed study of MUN in the first days and weeks of lactation showed a complex pattern of change. Overall, day $1 \mathrm{MUN}$ was $11.7 \pm 0.8 \mathrm{mg} / \mathrm{dL}(\mathrm{n}=49)$, but increased to peak $2.1 \mathrm{mg} / \mathrm{dL}$ greater on day 6 (13.8 \pm $0.12 \mathrm{mg} / \mathrm{dL}, \mathrm{n}=1087$ ), and thereafter, MUN declined gradually toward a nadir on d $28(12.5 \pm 0.10 \mathrm{mg} / \mathrm{dL}$, data not shown). Although the timing of those events was relatively similar, there were substantial differences between parity groups (Figure 4). First, d-1 MUN was lower in multiparous than in primiparous cows, maybe in part because of a difference in volume of colostrum. Second, peak and nadir MUN were relatively insensitive to FCM yield in primiparous cows, but increased with yield of FCM in multiparous cows. Third, for FCM $<25$ $\mathrm{kg} / \mathrm{d}$, parity had little effect on the pattern of change in MUN, but differences between parity groups became more evident with increasing milk production (Figure 4).

Test-day MUN was elevated for both low and high FCM during the first week of lactation (data not shown). When wk-1 FCM yield was $5,15,30$, and $50 \mathrm{~kg} / \mathrm{d}$, MUN averaged $14.6 \pm 1.1,13.0 \pm 0.3,13.6 \pm 0.1$, and $14.2 \pm$ $0.3 \mathrm{mg} / \mathrm{dL}$, respectively. However, in wk 5 , MUN increased with FCM and averaged $11.4 \pm 0.6,12.0 \pm 0.3$, $12.2 \pm 0.1$, and $13.3 \pm 0.1 \mathrm{mg} / \mathrm{dL}$ when FCM was 5,15 , 30 , and $50 \mathrm{~kg} / \mathrm{d}$, respectively.

Variation associated with milk yield and parity in Holsteins. Parity had a distinct effect on the pattern of change in test-day MUN with increasing FCM yield (Figure 5). In primiparous cows, MUN remained constant $(12.6 \pm 0.03 \mathrm{mg} / \mathrm{dL})$ for $\mathrm{FCM} \leq 42 \mathrm{~kg} / \mathrm{d}$, but declined linearly at a rate of $0.050 \pm 0.008 \mathrm{mg} / \mathrm{dL}$ per kilogram as FCM increased from 43 to $60 \mathrm{~kg} / \mathrm{d}$. In contrast, MUN in multiparous cows increased linearly by $0.061 \pm 0.003$ $\mathrm{mg} / \mathrm{dL}$ per kilogram as FCM increased to $28 \mathrm{~kg} / \mathrm{d}$ and by $0.027 \pm 0.001 \mathrm{mg} / \mathrm{dL}$ per $\mathrm{kg}$ as FCM increased from 29 to $58 \mathrm{~kg} / \mathrm{d}$. However, in the range of 59 to $82 \mathrm{~kg} / \mathrm{d}$, MUN declined at a rate of $0.057 \pm 0.006 \mathrm{mg} / \mathrm{dL}$ per kilogram of FCM.

\section{Analyses of Variance}

Holstein. Test-day MUN of the 48 factorial combinations in primiparous and multiparous cows was $12.55 \pm$ 


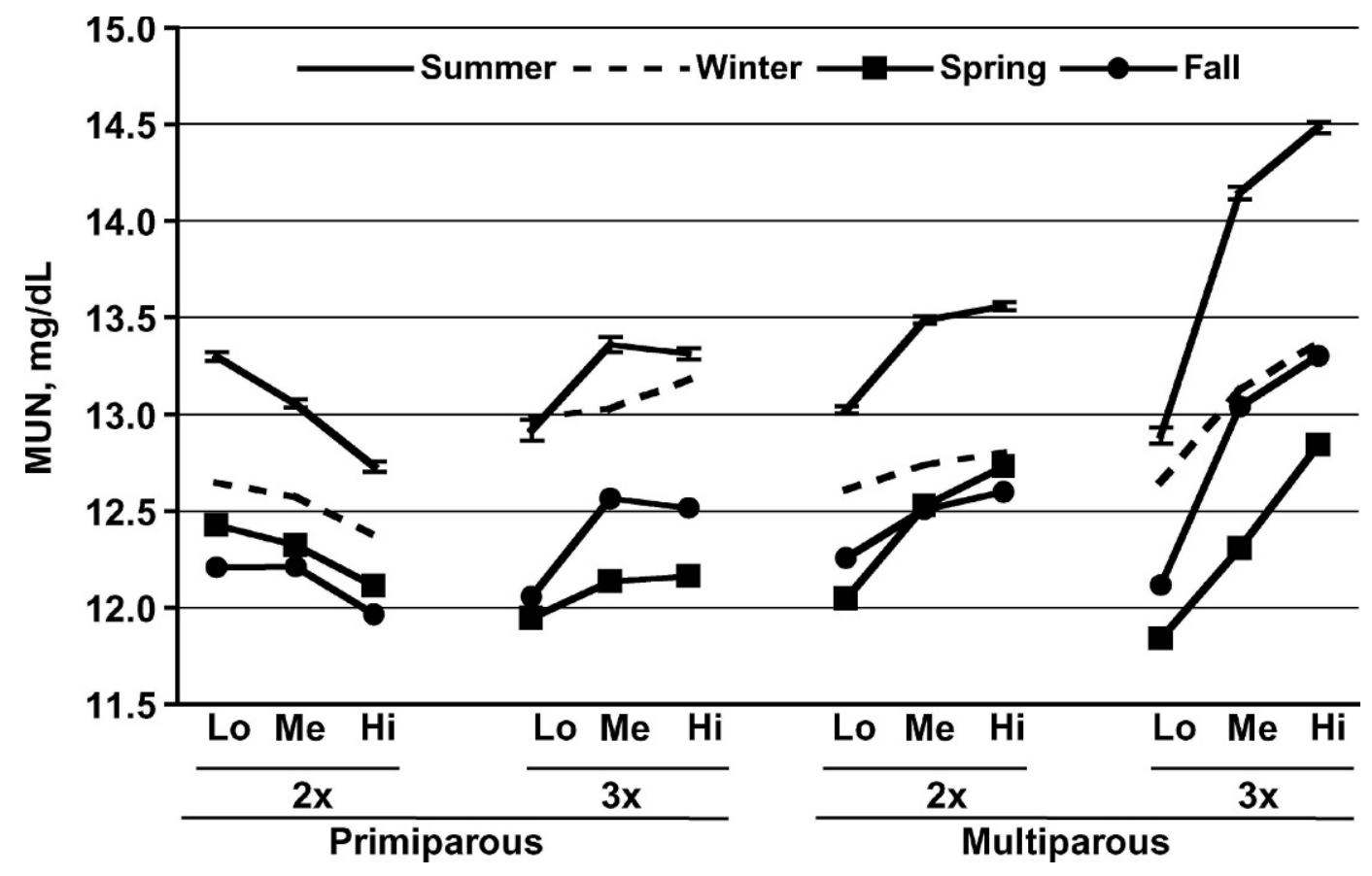

Figure 6. Change in test-day MUN associated with season, milking frequency ( $2 \times$ vs. $3 \times$ ), and yield of $4 \%$ FCM classified into 1 of 3 FCM categories (FCMc; $\mathrm{Lo}=$ bottom third, $\mathrm{Me}=$ middle third, and $\mathrm{Hi}=$ top third) in primiparous and multiparous Holsteins. In each parity group, the milking frequency $\times$ season interaction and the milking frequency $\times$ FCMc were significant. The vertical bars are SE, shown for the summer only, average $\mathrm{n}$ for each data point was 6203 , but ranged from 1054 to 13,671 .

0.69 and $12.83 \pm 0.76 \mathrm{mg} / \mathrm{dL}$, respectively. In both parity groups, the stepwise analysis resulted in final models that included sample type, season, milking frequency $\times$ season, and milking frequency $\times$ FCMc. Milking frequency was not significant in either parity group, and FCMc was significant in multiparous, but not primiparous, cows (Table 4). The base of adjustment for coefficients presented in Appendix Table 1 was the test-day MUN of cows in high FCMc, milked $3 \times$ a day on evening sampling schedule in the fall. Overall, test-day MUN was 1.0 (13.1 vs. $12.1 \mathrm{mg} / \mathrm{dL}$ ) and $0.9 \mathrm{mg} / \mathrm{dL}$ (13.3 vs. $12.4 \mathrm{mg} / \mathrm{dL}$ ) greater for evening vs. morning samples in primiparous and multiparous cows, respectively. In interpreting the impact of milking frequency, season and FCMc, interactions had to be taken into account. The nature of the milking frequency $\times$ season interaction differed between the parity groups (Figure 6 ). In the case of primiparous cows, MUN was greater in the spring than in the fall when cows were milked $2 \times$, but the reverse was true when cows were milked $3 \times$ per day, regardless of milk yield category. In the case of multiparous cows, however, average MUN over the $3 \mathrm{FCMc}$, was greater when cows were milked $3 \times$ compared with $2 \times$ per day in all 4 seasons, but the magnitude of the differences varied among seasons and averaged $0.43,0.09,0.69$, and $0.52 \mathrm{mg} / \mathrm{dL}$ in the winter, spring, summer, and fall, respectively. The nature of the milking frequency $\times \mathrm{FCMc}$ interaction varied also with parity. In the case of primiparous cows milked twice, MUN declined as FCM increased, but essentially the reverse was true for cows milked $3 \times$ per day (Figure 6 ). In the case of multiparous cows, MUN always increased with an increase in FCM, but the magnitude of the increase was much greater when cows were milked $3 \times$ than $2 \times$ per day.

Jersey. The impact of milking frequency could not be explored in Jerseys due to the lack of sufficient data for $3 \times$ milking. Test-day MUN for the 24 factorial combinations in morning and evening samples was $13.22 \pm 1.35$ and $13.98 \pm 1.30 \mathrm{mg} / \mathrm{dL}$, respectively. Final model for both sample types included season and $\mathrm{FCMc} \times$ season as significant effects, and FCMc $\times$ parity as a tendency. Parity did not influence test-day MUN in either analysis, but FCMc was significant for morning samples only (Table 5). The base of adjustment for coefficients presented in Appendix Table 2 was the fall test-day MUN of multiparous cows in high FCMc.

In the case of morning samples, MUN decreased with increasing milk production, strongly in the summer and the winter, marginally in the fall, but not at all during the spring (data not shown). In addition, for morning samples, MUN declined only slightly with milk production in multiparous cows $(13.3 \pm 0.2,13.1 \pm 0.2$, and $13.0 \pm 0.2 \mathrm{mg} / \mathrm{dL}$, for bottom, middle, and top FCMc, respectively), but declined sharply in primiparous cows 
$(14.8 \pm 0.3,13.2 \pm 0.2$, and $11.7 \pm 0.2 \mathrm{mg} / \mathrm{dL}$ for bottom, middle, and top FCMc, respectively). For evening samples, MUN increased with milk production in the winter and the spring, was unaffected by milk production in the fall, but decreased sharply with an increase in milk production in the summer (data not shown). Also in evening samples, MUN increased sharply with FCMc in multiparous cows $(13.0 \pm 0.2,13.9 \pm 0.2$, and $15.3 \pm 0.2$ $\mathrm{mg} / \mathrm{dL}$ for bottom, middle, and top FCMc, respectively), but in primiparous cows, MUN was lower in high-producing cows relative to the other 2 groups $(14.3 \pm 0.2,14.4$ \pm 0.2 , and $13.4 \pm 0.2 \mathrm{mg} / \mathrm{dL}$ for bottom, middle, and top FCMc, respectively).

Brown Swiss. As for the Jersey data, the impact of milking frequency could not be explored in Brown Swiss. Test-day MUN for the data set of 24 observations in morning and evening samples was $13.78 \pm 1.18$ and 15.20 $\pm 2.00 \mathrm{mg} / \mathrm{dL}$, respectively. Final model included season, FCMc, and FCMc $\times$ season for morning samples but season, FCMc, and FCMc $\times$ parity for evening samples. Parity did not influence test-day MUN of evening samples (Table 6). The base of adjustment for coefficients presented in Appendix Table 3 was the fall test-day MUN of cows in the high FCMc for morning samples, but the fall test-day MUN of multiparous cows in the high FCMc for evening samples.

In the case of morning samples, season, FCMc, and the season $\times$ FCMc interaction accounted for $91 \%$ of the total variation in MUN. The season $\times$ FCMc interaction was due in part to different rates of increase in MUN with increased milk yield in the winter, spring, and summer and the failure of the fall MUN values in highest producing group to increase relative to the middle production group (data not shown). For evening samples, season, FCMc, and the parity $\times$ FCMc interaction accounted also for $91 \%$ of total variation in MUN. The parity $\times$ FCMc interaction was associated with a failure for MUN for top producing primiparous cows to increase above MUN of cows in middle production group, as was the case for multiparous cows (data not shown).

\section{DISCUSSION}

The recent studies of Johnson and Young (2003), Arunvipas et al. (2003), Godden et al. (2001), and RajalaSchultz and Saville (2003) focused on the variation in MUN with DHI-related measurements from commercial farms in different parts of Canada and the United States. Such studies are limited by the lack of dietary information and the likely confounding between feeding practices and some of the DHI-related measurements. However, they are useful for the identification of factors and combination of factors (i.e., interactions) that contribute to variation in test-day MUN. Working with Holstein data, Arunvipas et al. (2003) indicated that all firstorder interactions in their model were significant, but the magnitude of the effects was small. Rajala-Schultz and Saville (2003) considered first-order interactions only among main effects that had been selected for unconditional association with MUN, but their final model did not include interactions. In the present study, however, the significance of 3-way or 4-way interactions in the initial models were numerous and led to separate analyses by parity groups in Holstein and by sample type in Jerseys and Brown Swiss. The size of the data set used here was much larger than in any comparable study to date, which provided an opportunity for detailed explorations of interactions in three different breeds.

\section{Fixed Effects and Interactions for Primiparous and Multiparous Holsteins}

Parity and yield of FCM. In the final Holstein models, MUN was influenced almost entirely by the same factors and interactions in both parity groups. One exception, however, was the change in MUN with FCMc, which was significant for multiparous but not for primiparous cows (Table 4). Figure 5 showed that the latter statistical inference was true as long as FCM was less than $42 \mathrm{~kg} / \mathrm{d}$. Milk urea $\mathrm{N}$ was predicted to increase with milk production (Jonker et al., 1999), and such results were confirmed later. For example, Godden et al. (2001) reported a quadratic relationship between milk yield and MUN, whereas Arunvipas et al. (2003) reported a linear increase of $0.05 \mathrm{mg} / \mathrm{dL}$ per additional $\mathrm{kg}$ of milk production from the 25th to the 75th percentile of their data set. Our study, however, showed that the association between MUN and FCM was drastically different between primiparous and multiparous cows (Figure 5). The exact nature of the parity difference remains unclear, but suggests differences in the fate of metabolizable protein as the need and supply of energy (carbon) and AA vary due to parity and level of milk production. No other report indicated a decline in MUN for the highest milk production levels as found here in both primiparous and multiparous cows. The reason for this decline is unclear, but warrants further investigation in the efficiency of use of dietary CP in unusually high-producing dairy cows.

Sample type. Sample type influenced MUN but did not interact with other factors in both parity groups. The evening minus morning difference was $1.0 \mathrm{mg} / \mathrm{dL}$ in this study compared with $0.72 \mathrm{mg} / \mathrm{dL}$ reported in Godden et al. (2001), who suggested that greater MUN in evening samples might be related to shorter feeding-to-milking interval compared with morning samples. Gustafsson and Palmquist (1993) showed that MUN varied with time after feeding. However, additional factors are likely to influence this difference because in the present study, 
MUN was the same whether morning samples were collected in cows milked $2 \times$ or $3 \times$ per day $(12.3 \pm 0.01$ and $12.3 \pm 0.02, \mathrm{mg} / \mathrm{dL}$, respectively). Similarly, evening values were relatively constant whether cows were milked $2 \times$ or $3 \times$ per day $(13.2 \pm 0.01$ and $13.4 \pm 0.02 \mathrm{mg} / \mathrm{dL}$, respectively).

Milking frequency, season, and FCMc. To our knowledge, this study is the first to report the association between milking frequency and MUN. Although there was no main effect, milking frequency interacted significantly but in different ways, with both season and FCMc in both parity groups (Table 4; Figure 6). Careful interpretation of these results is warranted because milking frequency per se may be confounded with factors such as frequency of feeding, number of rations fed to the lactating herd and other possible differences in herds on a $2 \times$ vs. $3 \times$ milking schedule. Although the true nature of these interactions remains unclear, their statistical and biological significance highlights the need to interpret MUN records separately for each combination of parity group, milking frequency, level of production and season.

The main effect of season was the second largest source of variation in Holstein MUN (Table 4). The data in Figure 6 agreed with reports showing that MUN is consistently greatest in the summer (Godden et al., 2001; Rajala-Schultz and Saville, 2003). However, the lowest MUN was in the spring in Godden et al. (2001) but depended on milk production level of the herd in RajalaSchultz and Saville (2003). In the present study, the lowest MUN in primiparous cows was observed in the fall, when milked twice, but in the spring when milked 3 times/d, whereas in multiparous cows, the lowest MUN was either in the fall or the spring depending on FCMc when milked twice, but in the spring when milked 3 times/d (Figure 6).

\section{Fixed Effects and Interactions for Morning and Evening Samples in Jerseys and Brown Swiss}

Adjusted $\mathrm{r}^{2}$ indicated better fit for Brown Swiss than for Jersey models (Tables 5 and 6). The absence of a main effect of parity in these models agreed with the report of Johnson and Young (2003) who found no difference in MUN between lactation 1 and lactation 2, but a slight decrease of questionable biological relevance between lactation 2 and lactation 3 in Jerseys. However, our study showed that parity interacted with FCMc, as a tendency in morning and evening samples of Jerseys (Table 5), but significantly in evening samples of Brown Swiss (Table 6). The effect of season on test-day MUN of Jerseys and Brown Swiss had not been reported earlier, neither was the FCMc $\times$ season interaction, which was significant in both Jersey models, but only for the morning samples in Brown Swiss.

\section{The Nature of Breed Differences}

Holstein, Jerseys and Brown Swiss in singlebreed herds. In this study, test-day MUN were higher for Brown Swiss and Jerseys compared with Holsteins. Higher MUN in Jerseys compared with Holsteins agreed with the results of Arunvipas et al. (2003), but disagreed with those of Johnson and Young (2003). When fed the same diet, MUN was greater in Holsteins compared with Jerseys (Rodriguez et al., 1997; Rastani et al., 2001) or the same in both breeds (Kauffman and St Pierre, 2001). As there is no evidence of differences in efficiency of use of metabolizable protein for maintenance or milk (protein) production (NRC, 2001), true genetic differences are not likely to contribute largely to the differences observed among breeds in this study. But genetic differences should not be completely disregarded as MUN heritability greater than 0.4 has been reported in Holsteins (Wood et al., 2003). However, because the relationship between MUN and urinary N per unit of BW was found to be a single linear function regardless of whether the cow was a Jersey or a Holstein (Kauffman and St Pierre, 2001), all else being equal, smaller breeds or cows with lower BW should have lower MUN than larger breeds or heavier cows. Furthermore, higher milk protein production is expected to result in higher MUN (Jonker et al., 1999; Nousiainen et al., 2004). Thus, in contrast to our findings and those of Arunvipas et al. (2003), but in agreement with Johnson and Young (2003), heavier and higher-producing cows should have greater MUN than lighter and lower-producing cows. Therefore, in comparing single-breed test-day MUN in this study, differences due to BW or milk production particularly between Jerseys and Holsteins, were overshadowed by other factors, most likely feeding and management practices. This contention was supported in part by the comparison of the changes in FCM yield (data not shown) and corresponding changes in MUN for cows in single-breed herds vs. multiple-breed herds and the ANOVA structure showing that 86,84 , and $93 \%$ of the variation in MUN was associated with either testday or herd rather than cow for Holstein, Jerseys, and Brown Swiss, respectively (Table 3).

Breeds per herd. Results of this study indicated that mean test-day MUN may be influenced by the presence of multiple breeds in a herd. The number of Jerseys, Brown Swiss, and Holsteins in multiple-breed herds was 586,353 , and 15,347 , respectively. Hence, in this study, the Jerseys and Brown Swiss in multiple-breed herds were "minority breeds" in predominantly Holstein herds. It was not possible to know whether the minority breeds 
were fed and managed similarly or differently than herd mates. Nevertheless, these results warrant careful interpretation of herd MUN averages when multiple breeds are present in the herd or when bulk tank sample includes milk from multiple breeds.

\section{Other Sources of Variation and Interactions}

Month and year. Large monthly variations in testday MUN (Figure 1) agreed with other reports (Godden et al., 2001; Arunvipas et al., 2003), but no consistent pattern emerged from comparing monthly values across studies or across years as in this study. Specific reasons for large and inconsistent temporal variations are difficult to identify, but suggest that industry or historical baselines within a herd may not be reliable in interpreting monthly MUN averages unless adjustments have been made to standardize values for certain sources of variations. Compared with monthly data, seasonal averages may provide an aggregate value that reflect better the overall impact of environmental factors (e.g., temperature, humidity, and daylight), changes in feeding program (e.g., spring grazing), level of milk production, and calving pattern throughout the year.

Early lactation MUN in Holsteins. Both Arunvipas et al. (2003) and Rajala-Schultz and Saville (2003) reported that the pattern of change in MUN resembled a lactation curve when MUN data were summarized on a 30-d interval basis. This pattern was first predicted by Jonker et al. (1999), and later it was shown that it varied with parity (Godden et al., 2001). However, in this study, average MUN was the highest during the first month of lactation (Figure 3). Upon further analysis, the change in MUN during this period showed a complex pattern. Availability of data has revealed an early peak (Figure 4), which may have been missed in earlier reports. The rise in MUN the first $3 \mathrm{~d}$ after calving should be interpreted carefully as the data comes from colostrum and transition milk. However, this rise and the subsequent pattern of change in the first few weeks after calving may also reflect the changing metabolism of the cow. A recent study indicated that MUN in the first 3 wk of lactation was positively correlated with production efficiency (FCM/DMI), but negatively correlated with DMI (Wattiaux and Karg, 2004a), suggesting that MUN was more reflective of the energy and protein balance of the cow than the adequacy of dietary inputs in the first weeks after calving. The pattern of change in MUN shortly after calving, as found in this report, and the fact that the height of the early MUN peak depended on level of production (Figure 4) reinforced this contention, especially in multiparous cows. The height of the peak and the rate of decline afterward may be indicative of the amount and extent of hepatic deamination of dietary AA or from body protein mobilization to meet cows' need for gluconeogenesis.

\section{CONCLUSIONS}

In this study, test-day MUN was higher for Jerseys and Brown Swiss than for Holsteins. However, there was an effect depending on whether a cow belonged to a single-breed herd or a multiple-breed herd, especially for Jerseys and Brown Swiss. Using MUN $\geq 14.5 \mathrm{mg} / \mathrm{dL}$ as a threshold, 93 out of 533 (17\%) Holstein herds, 8 out of 17 Jersey herds, and 4 out of 12 Brown Swiss herds in this study would most likely benefit from adjusting diet composition to improve efficiency of $\mathrm{N}$ use. Most of the test-day MUN variation was associated with transient factors influencing MUN on the day of test or factors related to herd management rather than cow. Thus, industry or herd baselines may be difficult to interpret unless adjusted for predictable sources of variation. In this study, adjustment coefficients were obtained from separate analysis of primiparous and multiparous in Holstein data and separate analysis of morning and evening samples in Jerseys and Brown Swiss.

\section{ACKNOWLEDGMENTS}

The authors would like to thank J. A. Bleck for access to the dataset and permission to use the data and to Ron Curran (Ag Source, CRI International, Verona, WI) for his practical and thoughtful ideas and permission to allow publishing of the regression coefficients.

\section{REFERENCES}

Arunvipas, P., I. R. Dohoo, J. A. VanLeeuwen, and G. P. Keefe. 2003. The effect of non-nutritional factors on milk urea nitrogen levels in dairy cows in Prince Edward Island, Canada. Prev. Vet. Med. 59:83-93.

Broderick, G. A., and M. K. Clayton. 1997. A statistical evaluation of animal and nutritional factors influencing concentrations of milk urea nitrogen. J. Dairy Sci. 80:2964-2971.

Godden, S. M., K. D. Lissemore, D. F. Kelton, K. E. Leslie, J. S. Walton, and J. H. Lumsden. 2001. Factors associated with milk urea nitrogen concentrations in Ontario dairy cows. J. Dairy Sci. 84:107-114.

Godden, S., R. Bey, J. Reneau, R. Farnsworth, and M. LaValle. 2002. Field validation of a milk-line sampling device for monitoring milk component data. J. Dairy Sci. 85:2192-2196.

Gustafsson, A. H., and D. L. Palmquist. 1993. Diurnal variation of rumen ammonia, serum urea, and milk urea in dairy cows at high and low yields. J. Dairy Sci. 76:475-484.

Hof, G., M. D. Vervoorn, P. J. Lenaers, and S. Tamminga. 1997. Milk urea nitrogen as a tool to monitor the protein nutrition of dairy cows. J. Dairy Sci. 80:3333-3340.

Johnson, R. G., and A. J. Young. 2003. The association between milk urea nitrogen and DHI production variables in western commercial dairy herds. J. Dairy Sci. 86:3008-3015.

Jonker, J. S., R. A. Kohn, and R. A. Erdman. 1999. Milk urea nitrogen target concentration for lactating dairy cows fed according to national research council recommendations. J. Dairy Sci. 82:12611273.

Jonker, J. S., R. A. Kohn, and J. High. 2002. Use of milk urea nitrogen to improve dairy cow diets. J. Dairy Sci. 85:939-946. 
Kauffman, A. J., and N. R. St-Pierre. 2001. The relationship of milk urea nitrogen to urine nitrogen excretion in Holstein and Jersey cows. J. Dairy Sci. 84:2284-2294.

Kohn, R. A., K. R. French, and E. Russek-Cohen. 2004. A comparison of instruments and laboratories used to measure milk urea nitrogen in bulk-tank milk samples. J. Dairy Sci. 87:1848-1853.

Kohn, R. A., K. F. Kalscheur, and E. Russek-Cohen. 2002. Evaluation of models to estimate urinary nitrogen and expected milk urea nitrogen. J. Dairy Sci. 85:227-233.

NRC. 2001. Nutrient Requirements of Dairy Cattle. 7th rev. ed. Natl. Acad. Press, Washington, DC.

Nousiainen, J. K., J. Shingfield, and P. Huhtanen. 2004. Evaluation of milk urea nitrogen as a diagnostic of protein feeding. J. Dairy Sci. 87:386-398.

Peterson, A. B., K. R. French, E. Russek-Cohen, and R. A. Kohn. 2004. Comparison of analytical methods and the influence of milk components on milk urea nitrogen recovery. J. Dairy Sci. $87: 1747-1750$.
Rajala-Schultz, P. J., and W. J. A. Saville. 2003. Source of variation in milk urea nitrogen in Ohio dairy herds. J. Dairy Sci. 86:1653-1661.

Rastani, R. R., S. M. Andrew, S. A. Zinn, and C. J. Sniffen. 2001. Body composition and estimated tissue energy balance in Jersey and Holstein cows during early lactation. J. Dairy Sci. 84:1201-1209.

Rodriguez, L. A., C. C. Stallings, J. H. Hebein, and M. L. McGilliard. 1997. Effect of degradability of dietary protein and fat on ruminal, blood, and milk components of Jersey and Holstein cows. J. Dairy Sci. 80:353-363.

Wattiaux, M. A., and K. L. Karg. 2004a. Protein level for alfalfa and corn silage-based diets: I. Lactational response and milk urea nitrogen. J. Dairy Sci. 87:3480-3491.

Wattiaux, M. A., and K. L. Karg. 2004b. Protein level for alfalfa and corn silage based diets: II. Nitrogen balance and manure characteristics. J. Dairy Sci. 87:3492-3502.

Wood, G. M., P. J. Boettcher, J. Jamrozik, G. B. Jansen, and D. F. Kelton. 2003. Estimation of genetic parameters for concentrations of milk urea nitrogen. J. Dairy Sci. 86:2462-2469.

\section{APPENDIX}

Table 1. Model-predicted estimates of variation in MUN ( $\mathrm{mg} / \mathrm{dL})$ of primiparous and multiparous Holsteins.

\begin{tabular}{|c|c|c|c|c|c|c|c|c|}
\hline \multirow[b]{2}{*}{ Factor } & \multirow[b]{2}{*}{ Level } & & \multicolumn{3}{|c|}{ Primiparous } & \multicolumn{3}{|c|}{ Multiparous } \\
\hline & & & Estimate $^{1}$ & $\mathrm{SE}$ & $P$-value & Estimate & $\mathrm{SE}$ & $P$-value \\
\hline Intercept & & & 12.843 & 0.100 & $<0.0001$ & 13.513 & 0.109 & $<0.0001$ \\
\hline Season2 & $\begin{array}{l}\text { Winter } \\
\text { Spring } \\
\text { Summer } \\
\text { Fall }\end{array}$ & & $\begin{array}{r}0.735 \\
-0.241 \\
0.842 \\
0.000\end{array}$ & $\begin{array}{l}0.111 \\
0.111 \\
0.111 \\
\ldots\end{array}$ & $\begin{array}{l}<0.0001 \\
0.036 \\
<0.0001 \\
\ldots\end{array}$ & $\begin{array}{r}0.307 \\
-0.424 \\
1.099 \\
0.000\end{array}$ & $\begin{array}{l}0.121 \\
0.121 \\
0.121 \\
\ldots .\end{array}$ & $\begin{array}{l}0.016 \\
0.001 \\
<0.0001 \\
\ldots\end{array}$ \\
\hline Sample type & $\begin{array}{l}\text { Morning } \\
\text { Evening }\end{array}$ & & $\begin{array}{r}-1.026 \\
0.000\end{array}$ & $\begin{array}{l}0.055 \\
\ldots\end{array}$ & $\begin{array}{l}<0.0001 \\
\ldots\end{array}$ & $\begin{array}{r}-0.885 \\
0.000\end{array}$ & $\begin{array}{l}0.061 \\
\ldots\end{array}$ & $\begin{array}{l}<0.0001 \\
\ldots .\end{array}$ \\
\hline $\mathrm{MF}^{3}$ & $\begin{array}{l}2 \times \\
3 \times\end{array}$ & & $\begin{array}{r}-0.274 \\
0.000\end{array}$ & $\begin{array}{l}0.135 \\
\ldots\end{array}$ & $\begin{array}{l}0.051 \\
\ldots\end{array}$ & $\begin{array}{r}-0.383 \\
0.000\end{array}$ & $\begin{array}{l}0.148 \\
\ldots\end{array}$ & $\begin{array}{l}0.014 \\
\ldots\end{array}$ \\
\hline $\mathrm{FCMc}^{4}$ & $\begin{array}{l}\mathrm{Lo} \\
\mathrm{Me} \\
\mathrm{Hi}\end{array}$ & & $\begin{array}{r}-0.323 \\
-0.044 \\
0.000\end{array}$ & $\begin{array}{l}0.096 \\
0.096 \\
\ldots\end{array}$ & $\begin{array}{l}0.002 \\
0.649 \\
\ldots\end{array}$ & $\begin{array}{r}-1.036 \\
-0.288 \\
0.000\end{array}$ & $\begin{array}{l}0.105 \\
0.105 \\
\ldots\end{array}$ & $\begin{array}{c}<0.0001 \\
0.010 \\
. .\end{array}$ \\
\hline MF $\times$ season & $\begin{array}{l}\text { Winter } \\
\text { Winter } \\
\text { Spring } \\
\text { Spring } \\
\text { Summer } \\
\text { Summer } \\
\text { Fall } \\
\text { Fall }\end{array}$ & $\begin{array}{l}2 \times \\
3 \times \\
2 \times \\
3 \times \\
2 \times \\
3 \times \\
2 \times \\
3 \times\end{array}$ & $\begin{array}{l}-0.326 \\
0.000 \\
0.350 \\
0.000 \\
0.0004 \\
0.000 \\
0.000 \\
0.000\end{array}$ & $\begin{array}{l}0.156 \\
\ldots \\
0.156 \\
\ldots \\
0.156 \\
\ldots \\
\ldots \\
\ldots\end{array}$ & $\begin{array}{l}0.045 \\
\ldots \\
0.032 \\
\ldots \\
0.998 \\
\ldots \\
\ldots \\
\ldots\end{array}$ & $\begin{array}{r}-0.014 \\
0.000 \\
0.391 \\
0.000 \\
-0.218 \\
0.000 \\
0.000 \\
0.000\end{array}$ & $\begin{array}{l}0.171 \\
\ldots \\
0.171 \\
\ldots \\
0.171 \\
\ldots \\
\ldots \\
\ldots\end{array}$ & $\begin{array}{l}0.934 \\
\ldots \\
0.029 \\
\ldots \\
0.212 \\
\ldots \\
\ldots \\
\ldots\end{array}$ \\
\hline $\mathrm{MF} \times \mathrm{FCMc}$ & $\begin{array}{l}2 \times \\
2 \times \\
2 \times \\
3 \times \\
3 \times \\
3 \times\end{array}$ & $\begin{array}{l}\mathrm{Lo} \\
\mathrm{Me} \\
\mathrm{Hi} \\
\mathrm{Lo} \\
\mathrm{Me} \\
\mathrm{Hi}\end{array}$ & $\begin{array}{l}0.592 \\
0.267 \\
0.000 \\
0.000 \\
0.000 \\
0.000\end{array}$ & $\begin{array}{l}0.135 \\
0.135 \\
\ldots \\
\ldots \\
\ldots \\
\ldots\end{array}$ & $\begin{array}{l}<0.001 \\
0.057 \\
\ldots \\
\ldots \\
\ldots \\
\ldots\end{array}$ & $\begin{array}{l}0.578 \\
0.184 \\
0.000 \\
0.000 \\
0.000 \\
0.000\end{array}$ & $\begin{array}{l}0.148 \\
0.148 \\
\ldots \\
\ldots \\
\ldots \\
\ldots\end{array}$ & $\begin{array}{l}<0.001 \\
0.224 \\
\ldots \\
\ldots \\
\ldots \\
\ldots\end{array}$ \\
\hline
\end{tabular}

${ }^{1}$ Zeros indicate level or combination of levels of each factor used as reference.

${ }^{2}$ Winter = December to February; Spring = March to May; Summer = June to August; Fall = September to November.

${ }^{3} \mathrm{MF}=$ Milking frequency.

${ }^{4} \mathrm{FCMc}$ low $(\mathrm{Lo})=$ bottom third, medium $(\mathrm{Me})=$ middle third, and high $(\mathrm{Hi})=$ top third in $4 \% \mathrm{FCM}$ yield. The 33 and 67 percentiles for FCM were 26.4 and $32.6 \mathrm{~kg} / \mathrm{d}$ for primiparous cows, and 28.7 and $38.1 \mathrm{~kg} / \mathrm{d}$ for multiparous cows, respectively. 
WATTIAUX ET AL.

Table 2. Model-predicted estimates of variation in MUN $(\mathrm{mg} / \mathrm{dL})$ of morning and evening samples for Jerseys.

\begin{tabular}{|c|c|c|c|c|c|c|c|}
\hline \multirow{2}{*}{ Factor } & & \multicolumn{3}{|c|}{ Morning samples } & \multicolumn{3}{|c|}{ Evening samples } \\
\hline & & Estimate $^{1}$ & $\mathrm{SE}$ & $P$-value & Estimate & $\mathrm{SE}$ & $P$-value \\
\hline Intercept & & 12.441 & 0.458 & $<0.0001$ & 13.784 & 0.682 & $<0.0001$ \\
\hline \multicolumn{8}{|l|}{ Parity } \\
\hline & & -1.123 & 0.410 & 0.023 & -1.406 & 0.610 & 0.047 \\
\hline$>1$ & & 0.000 & $\ldots$ & $\ldots$ & 0.000 & $\ldots$ & $\ldots$ \\
\hline \multicolumn{8}{|l|}{ Season $^{2}$} \\
\hline Winter & & 0.959 & 0.580 & 0.132 & 2.127 & 0.863 & 0.036 \\
\hline Spring & & 0.226 & 0.580 & 0.706 & 1.058 & 0.863 & 0.251 \\
\hline Summer & & 0.861 & 0.580 & 0.172 & 0.546 & 0.863 & 0.543 \\
\hline Fall & & 0.000 & $\ldots$ & $\ldots$ & 0.000 & $\ldots$ & $\ldots$ \\
\hline \multicolumn{8}{|l|}{$\mathrm{FCMc}^{3}$} \\
\hline Lo & & 0.414 & 0.648 & 0.539 & -1.447 & 0.965 & 0.168 \\
\hline $\mathrm{Me}$ & & -0.503 & 0.648 & 0.458 & -0.541 & 0.965 & 0.588 \\
\hline $\mathrm{Hi}$ & & 0.000 & $\ldots$ & $\ldots$ & 0.000 & $\ldots$ & $\ldots$ \\
\hline \multicolumn{8}{|c|}{ FCMc $\times$ parity } \\
\hline 1 & Lo & 2.626 & 0.580 & 0.001 & 2.615 & 0.863 & 0.014 \\
\hline 1 & $\mathrm{Me}$ & 1.535 & 0.580 & 0.027 & 1.971 & 0.863 & 0.048 \\
\hline 1 & $\mathrm{Hi}$ & 0.000 & $\ldots$ & $\ldots$ & 0.000 & $\ldots$ & $\ldots$ \\
\hline$>1$ & Lo & 0.000 & $\ldots$ & $\ldots$ & 0.000 & $\ldots$ & $\ldots$ \\
\hline$>1$ & $\mathrm{Me}$ & 0.000 & $\ldots$ & $\ldots$ & 0.000 & $\ldots$ & $\ldots$ \\
\hline$>1$ & $\mathrm{Hi}$ & 0.000 & $\ldots$ & $\ldots$ & 0.000 & $\ldots$ & $\ldots$ \\
\hline \multicolumn{8}{|c|}{ FCMc $\times$ season } \\
\hline Winter & Lo & -0.187 & 0.820 & 0.825 & -2.244 & 1.220 & 0.099 \\
\hline Winter & $\mathrm{Me}$ & 0.542 & 0.820 & 0.525 & -1.817 & 1.220 & 0.171 \\
\hline Winter & $\mathrm{Hi}$ & 0.000 & & & 0.000 & & $\ldots$ \\
\hline Spring & Lo & -1.584 & 0.820 & 0.085 & -0.967 & 1.220 & 0.449 \\
\hline Spring & $\mathrm{Me}$ & 0.177 & 0.820 & 0.834 & -0.440 & 1.220 & 0.727 \\
\hline Spring & $\mathrm{Hi}$ & 0.000 & & & 0.000 & & \\
\hline Summer & Lo & 0.879 & 0.820 & 0.311 & 2.652 & 1.220 & 0.058 \\
\hline Summer & $\mathrm{Me}$ & 2.126 & 0.820 & 0.029 & 1.165 & 1.220 & 0.365 \\
\hline Summer & $\mathrm{Hi}$ & 0.000 & $\ldots$ & $\ldots$ & 0.000 & $\ldots$ & $\ldots$ \\
\hline Fall & Lo & 0.000 & $\ldots$ & $\ldots$ & 0.000 & $\ldots$ & $\ldots$ \\
\hline Fall & $\mathrm{Me}$ & 0.000 & $\ldots$ & $\ldots$ & 0.000 & $\ldots$ & $\ldots$ \\
\hline Fall & $\mathrm{Hi}$ & 0.000 & $\ldots$ & $\ldots$ & 0.000 & $\ldots$ & $\ldots$ \\
\hline
\end{tabular}

${ }^{1}$ Zeros indicate level and combination of levels of each factor used as references.

${ }^{2}$ Winter $=$ December to February; Spring $=$ March to May; Summer $=$ June to August; Fall $=$ September to November.

${ }^{3}$ FCMc: low $(\mathrm{Lo})=$ bottom third, medium $(\mathrm{Me})=$ middle third, and high $(\mathrm{Hi})=$ top third in $4 \% \mathrm{FCM}$ yield. The 33 and 67 percentiles for Jersey test-day FCM records were 22.1 and $28.7 \mathrm{~kg} / \mathrm{d}$ for morning samples and 20.4 and $27.9 \mathrm{~kg} / \mathrm{d}$ for evening samples, respectively. 
Table 3. Model-predicted estimates of variation in MUN (mg/dL) of morning and evening samples for Brown Swiss.

\begin{tabular}{|c|c|c|c|c|c|c|c|}
\hline \multirow[b]{2}{*}{ Factor } & & \multicolumn{3}{|c|}{ Morning samples } & \multicolumn{3}{|c|}{ Evening samples } \\
\hline & & Estimate $^{1}$ & $\mathrm{SE}$ & $P$-value & Estimate & $\mathrm{SE}$ & $P$-value \\
\hline Intercept & & 14.705 & 0.252 & $<0.0001$ & 14.892 & 0.364 & $<0.0001$ \\
\hline \multicolumn{8}{|l|}{ Parity } \\
\hline 1 & & $\ldots$ & $\ldots$ & $\ldots$ & -1.577 & 0.421 & 0.002 \\
\hline$>1$ & & $\ldots$ & $\ldots$ & $\ldots$ & 0.000 & $\ldots$ & $\ldots$ \\
\hline \multicolumn{8}{|l|}{ Season $^{2}$} \\
\hline Winter & & 1.259 & 0.356 & 0.004 & 1.894 & 0.343 & $<0.0001$ \\
\hline Spring & & -1.260 & 0.356 & 0.004 & -0.036 & 0.343 & 0.919 \\
\hline Summer & & -0.774 & 0.356 & 0.050 & 3.906 & 0.343 & $<0.0001$ \\
\hline Fall & & 0.000 & $\ldots$ & $\ldots$ & 0.000 & $\ldots$ & $\ldots$ \\
\hline \multicolumn{8}{|l|}{$\mathrm{FCMc}^{3}$} \\
\hline Lo & & -0.933 & 0.356 & 0.022 & -2.803 & 0.421 & $<0.0001$ \\
\hline $\mathrm{Me}$ & & 0.159 & 0.356 & 0.662 & -0.121 & 0.421 & 0.778 \\
\hline $\mathrm{Hi}$ & & 0.000 & $\ldots$ & $\cdots$ & 0.000 & $\ldots$ & $\cdots$ \\
\hline \multicolumn{8}{|c|}{ FCMc $\times$ parity } \\
\hline 1 & Lo & 2.626 & 0.580 & $<0.001$ & 2.673 & 0.595 & $<0.001$ \\
\hline 1 & $\mathrm{Me}$ & 1.535 & 0.580 & 0.027 & 1.101 & 0.595 & 0.084 \\
\hline 1 & $\mathrm{Hi}$ & 0.000 & $\ldots$ & $\ldots$ & 0.000 & $\ldots$ & $\ldots$ \\
\hline$>1$ & Lo & 0.000 & $\ldots$ & $\ldots$ & 0.000 & $\ldots$ & $\ldots$ \\
\hline$>1$ & $\mathrm{Me}$ & 0.000 & $\ldots$ & $\ldots$ & 0.000 & $\ldots$ & $\ldots$ \\
\hline$>1$ & $\mathrm{Hi}$ & 0.000 & $\ldots$ & $\ldots$ & 0.000 & $\ldots$ & $\ldots$ \\
\hline \multicolumn{8}{|c|}{ FCMc $\times$ season } \\
\hline Winter & Lo & -2.486 & 0.504 & 0.000 & $\ldots$ & $\ldots$ & $\ldots$ \\
\hline Winter & $\mathrm{Me}$ & -1.081 & 0.504 & 0.053 & $\ldots$ & $\ldots$ & $\ldots$ \\
\hline Winter & $\mathrm{Hi}$ & 0.000 & $\ldots$ & $\ldots$ & $\ldots$ & $\ldots$ & $\ldots$ \\
\hline Spring & Lo & -0.662 & 0.504 & 0.214 & $\ldots$ & $\ldots$ & $\ldots$ \\
\hline Spring & $\mathrm{Me}$ & -0.715 & 0.504 & 0.181 & $\ldots$ & $\ldots$ & $\ldots$ \\
\hline Spring & $\mathrm{Hi}$ & 0.000 & $\ldots$ & $\ldots$ & $\ldots$ & $\ldots$ & $\ldots$ \\
\hline Summer & Lo & 0.051 & 0.504 & 0.921 & $\ldots$ & $\ldots$ & $\ldots$ \\
\hline Summer & $\mathrm{Me}$ & -0.810 & 0.504 & 0.134 & $\ldots$ & $\cdots$ & $\cdots$ \\
\hline Summer & $\mathrm{Hi}$ & 0.000 & $\ldots$ & $\ldots$ & $\ldots$ & $\ldots$ & $\ldots$ \\
\hline Fall & Lo & 0.000 & $\ldots$ & $\cdots$ & $\ldots$ & $\cdots$ & $\cdots$ \\
\hline Fall & $\mathrm{Me}$ & 0.000 & $\ldots$ & $\ldots$ & $\ldots$ & $\ldots$ & $\ldots$ \\
\hline Fall & $\mathrm{Hi}$ & 0.000 & $\ldots$ & $\ldots$ & $\ldots$ & $\ldots$ & $\ldots$ \\
\hline
\end{tabular}

${ }^{1}$ Zeros indicate level or combination of levels of each factor used as references.

${ }^{2}$ Winter $=$ December to February; Spring $=$ March to May; Summer $=$ June to August; Fall $=$ September to November.

${ }^{3} \mathrm{FCMc}$ : low $(\mathrm{Lo})=$ bottom third, medium $(\mathrm{Me})=$ middle third, and high $(\mathrm{Hi})=$ top third in $4 \% \mathrm{FCM}$ yield. The 33 and 67 percentiles for Brown Swiss test-day FCM records were 21.2 and $29.5 \mathrm{~kg} / \mathrm{d}$ for morning samples and 21.8 and $31.3 \mathrm{~kg} / \mathrm{d}$ for evening samples, respectively. 